\title{
PARTICIPATING IN A DIVERSE WORLD: IMMIGRANT POLITICAL PARTICIPATION WITHIN DIVERSE COMMIUNITIES
}

\author{
by \\ Linda Catherine Kingsmill \\ BA (Hons.), McGill University, Montréal, Québec, 2007 \\ A Major Research Paper \\ presented to Ryerson University \\ in partial fulfillment of the requirements for the degree of \\ Master of Arts \\ in the Program of \\ Immigration and Settlement Studies
}

Toronto, Ontario, Canada, 2009

(C) Linda Catherine Kingsmill 2009 
I hereby declare that I am the sole author of this major research paper.

I authorize Ryerson University to lend this paper to other institutions or individuals for the purpose of scholarly research.

Sígnature

I further authorize Ryerson University to reproduce this paper by photocopying or by other means, in total, or in part, at the request of other institutions or individuals for the purpose of scholarly research. 


\title{
PARTICIPATING IN A DIVERSE WORLD: IMMIGRANT POLITICAL PARTICIPATION WITIIIN DIVERSE COMMUNITIES
}

\author{
Master of Arts \\ in the Program of \\ Immigration and Settlement Studies \\ (C) Linda Catherine Kingsmill 2009
}

\begin{abstract}
This literature review explores the relationship between neighbourhood diversity and political participation arguing that social capital is well-suited for assessing the political context created by communities. Emphasis is placed on the Canadian context which is characterized by a lack of scholarship. Particularly, this review explores how existing studies can explain the impact of community diversity on political participation and whether immigrants, as a group, are disproportionately affected by such diversity. This review also outlines how social capital might be useful in determining how context, such as, diversity, determines individuals' political behaviours. Generally speaking, this review finds that it is difficult to draw definitive conclusions regarding the effects of diversity on political participation and that there is an overwhelming empirical gap in the literature on immigrant political participation.
\end{abstract}

Key Words: Diversity; Heterogeneity; Immigrant; Political Participation; Voting 


\section{ACKNOWEDLEGMENTS}

I would like to thank all the people who have helped and inspired me during the process of writing this Major Research Paper.

I would like to extend a very special thank you to my supervisor, Dr. Daniel Rubenson, for introducing me to the topic of this Major Research Paper which is based on his teaching and own research- both of which have served as an inspiration. He has enriched my understanding of this topic immensely through both his insight and expertise. I am grateful for his suggestions, encouragement and kindness. It was truly a pleasure working under his supervision and I thank him for all of his time which he gave generously.

I am also thankful to have had the opportunity to work with Dr. Tracey Raney, who served as my second reader. I wish to express my gratitude for her helpful suggestions and feedback during the oral review process.

I especially would like to thank Neil, with whom I discussed numerous issues that are reflected in this literature review. I would like to thank him for all of his patience and for striking a harmonious balance between challenging and cheering me on.

My deepest gratitude goes to my family for their continued love and support. I wish to give a special thanks to my grandmother, Sally. Last but not least, my parents have been a constant source of support throughout all of my endeavours and without exception, this Major Research Paper wouldn't have been possible without them. 


\section{TABLE OF CONTENTS}

Introduction

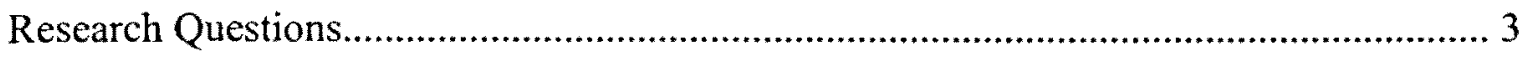

Operational Definitions..................................................................................................... 3

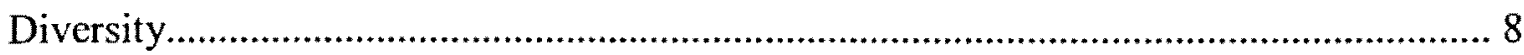

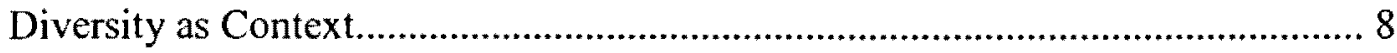

Diversity within Canadian Communities.......................................................... 11

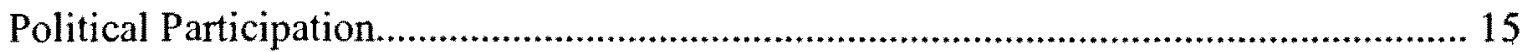

Traditional Models of Political Participation........................................................ 15

Overview of Studies on Immigrant Political Participation.................................... 22

Social Capital: Linking Political Participation and Diversity............................................ 31

Social Capita as Theory.......................................................................................... 32

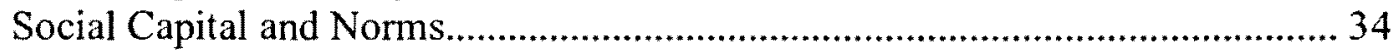

Social Capital and Trust........................................................................................ 37

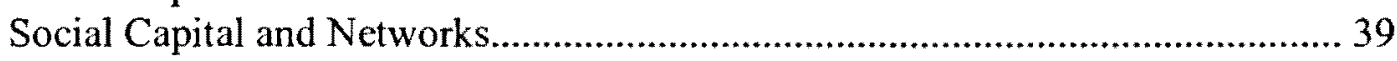

Social Capital and Collective Action..................................................................... 41

Measurement, Data and Methodological Approaches.................................................................... 44

Findings: An Overview of the Existing Literature

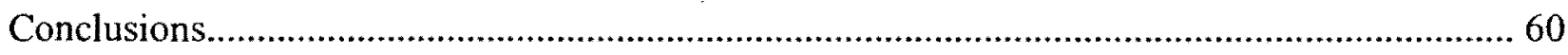

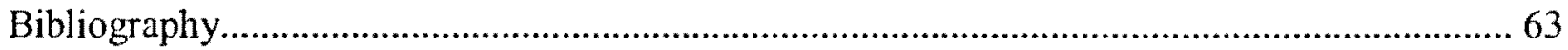




\section{LIST OF TABLES}

Table 1: Gini Indices of Concentration by Ethnic Group for Montréal, Toronto, Vancouver, 2001

Table 2: Percentage of Census Tracts in which 50\% and 90\% of Ethnic Population are Concentrated, Montréal, Toronto and Vancouver, 2001

Table 3: Voter Turnout in the 2004 and 2006 Federal Elections and The Percentage of Immigrants in Each Riding, Ontario.

\section{LIST OF FIGURES}

Figure I: Formal and Informal Political Participation According to Immigrant Status and Naturalization

Figure 2: Summary of Traditional Models of Political Participation............................................ 19

Figure 3: Summary of Immigrant Political Participation Models................................................. 30

Figure 4: Connecting Immigrant Voting to Social Capital and Neighbourhood Diversity.......... 44 


\section{INTRODUCTION}

Political scholars have long been interested in the political participation of citizens and more specifically, the question of who votes, who does not, and why (see Blais \& Young 1999; Campbell 2006; Rosenstone \& Hansen 1993; Wolfinger \& Rosenstone 1980; Verba et al. 1972). As an essential component of democracy, voting is something that has been both studied and a.: promoted having both scholarly and practical merit. Over time, scholars have developed models like socio-economic status and rational choice to better understand the political behaviours of citizens (see Aldrich 1993; Blais 2000; Nevitte et al. 2000; Verba et al. 1995). However, as citizens are increasingly composed of immigrants, attention is being devoted to determining whether foreign-born citizens' political behaviours can still be understood through the utilization of these traditional models of political participation.

Similarly, as migratory flows increase and immigrants from less traditional source countries settle in the developed world, scholars have become more and more interested in understanding the effects of diversity on state institutions, policies and social cohesion. In fact, it is becoming increasingly crucial to understand diversity as countries become progressively more diverse. By combining both literature on political participation and diversity, one can better understand the contextual effect of diversity on voting.

When it comes to the existing literature on diversity and political participation, there are two main opposing theoretical positions which have been advanced. The first claims that diversity inhibits political engagement through undermining social norms, networks and trust, all of which are arguably related to political participation (Putnam 2007; Alesina \& La Ferrara $2000 ; 2002)$. Also related to this perspective are increasing cross-pressures which similarly inhibit political engagement (Mutz 2002). Conversely, a second theoretical position contends 
that diversity promotes political engagement since there ought to be greater competition over resources and overall incentives to participate tend to be greater in diverse settings (Rubenson 2004; Oliver 2001). Of course, it is also possible that both extremes of heterogeneity and homogeneity increase the likelihood of voting or alternatively, that diversity has no significant effect on political participation.

The following literature review will investigate how diversity affects political participation, with a specific focus on the differences in the political engagement of immigrants and non-immigrants living in diverse settings. This review will also highlight immigrant political participation which has been relatively understudied compared to the political behaviours of native-borm citizens. Ultimately, this review seeks to determine whether immigrants and their subsequent political participation are disproportionately affected by diversity. The literature examined will be drawn from a variety of disciplines including politics, sociology, geography and economics.

This literature review will be presented in four sections. To begin, the first section will introduce the main research questions and establish the focus of this study as well as all relevant definitions. This will be followed by an examination of diversity as a contextual effect and as a framework for understanding neighbourhood context within Canadian society. Next, this review will explore the existing literature on immigrant political participation which will provide both background and relevance for this study. Lastly, this section will present a discussion of diversity, social cohesion and social capital and how these concepts are related to political engagement. Particular emphasis will be placed social capital.

The second section will explore issues of measurement, data and methodology, providing significance to the third section which will provide an overview and analysis of the existing 
literature on diversity and political participation. Here emphasis will be placed on contextual effects, ultimately determining whether diversity disproportionately affects immigrant political participation. Lastly, the fourth section of this review will conclude by making suggestions for further research.

\section{RESEARCII QUESTIONS}

The main questions this literature review seeks to answer are: (1) What is the impact of community diversity on political participation?; (2) How can social capital as a theory explain how context affects individual's political behaviours within diverse settings?; and lastly (3) Is immigrant political participation disproportionately affected by such diversity? These research questions are related to the larger body of existing studies which attempt to understand the political behaviour of native-born citizens and immigrants alike. Similar to these studies, this review will attempt to further our understanding of why some immigrants participate in politics while others abstain.

\section{OPERATIONAL DEFINITIONS}

There are a number of terms which will be utilized throughout this review. Although diversity can take on many meanings, here diversity refers to the ethnic heterogeneity of a community. In other words, a diverse or heterogeneous neighbourhood is one which is inhabited by people from a wide-range of ethnic backgrounds whereas a homogenous neighbourhood is inhabited by people predominantly from the same ethnic background.

Some of the literature reviewed, particularly that which originates from the United States defines diversity in terms of race. Although ethnic and racial diversity may connote two different 
things, they are directly related. Furthermore, in the Canadian context, ethnicity tends to be more salient than race whereas, the reverse is true in the United States (Qadeer 2003). Consequently, this study will draw upon examples of racial diversity in the United States and elsewhere but exercise caution when relating them to the Canadian context.

Neighbourhoods or communities, terms used interchangeably in this review, can indicate numerous types of geographical units including hamlets, streets, towns, cities and constituencies, to name a few. Various studies define neighbourhood diversity differently, for example, using the Gini Index, Index of Dissimilarity or Index of Ethnic Fragmentation (Hill \& Leighley 1999; Alesina \& La Ferarra 2002; Mesch 2002). Yet given that each index measures a different aspect of diversity, it is useful to consider multiple measures when determining the overall diversity of a given setting. Furthermore, all measures of diversity are conceptually similar and therefore, despite drawbacks and differences, each more or less assesses the ethnic composition of a given neighbourhood.

In the Canadian context, scholars have tended to measure diversity without the use of existing indices, to avoid having to characterize diversity as the difference between only two groups; a measure which has arguably been more suitable in studies of Blacks and Whites in the United States. For example, in his study of Canadian residential segregation, Mohammad Qadeer (2003) examined the percentage of census metropolitan areas (hereafter, CMAs) in which at least fifty percent of an ethnic group's total Toronto population resided. Similarly, other studies set different but similar percentages representing a proportion of a given ethnic group living within a specific geographical border (see Bauder \& Sharpe 2002; Doucet 1999; Fong 1996).

A second critical concept is political participation, which can be defined as any intentional activity seeking to influence government action. This can include voting, attending a 
protest or writing to a govcrnment official (Verba et al. 1995, 38). Sandra Burt (2002), however, notes that the concept of political participation is "straightforward" yet "imprecise" given that actions mean different things to different people in different contexts (233). Consequently, emphasis must be placed on the intentional nature of one's actions to influence political decisions.

Distinction must also be made between political and civic participation since motives for participation may be inherently different for each (Rubenson 2004). Following this logic, joining a voluntary association must be treated differently than canvassing door to door for an election candidate, unless the activities of the voluntary association are inherently political such as those of a political party. This study is strictly interested in political participation and consequently, civic participation will only be referenced as a plausible factor directly facilitating political participation.

When possible, this study will indicate which forms of political participation were studied. Nonetheless, most of the studies considered in this review look at voting. This is because voting tends to be more easily measured through election studies than other forms of political participation, particularly those which are less formal. Additionally, voting in elections, whether at the national, regional or municipal level is especially important because it is a clear indicator of immigrant political integration. Although protest activities may also indicate political incorporation, such activities may also be transnational in nature, intending to influence government actions overseas and thus, the main intent may not necessarily be to influence Canadian government action. Daiva Stasiulis (1997) also makes this distinction in her overview of immigrant political participation in Canada. 
The neighbourhoods drawn from the existing literature are found across the globe from Canada, Australia, Belgium, Denmark, Israel, the United Kingdom, the Netherlands and Israel but mainly from the United States. Such a cross-national comparative perspective provides rich examples which in many cases are relatable to the Canadian context. As this study will reveal, there is a relative gap in Canadian scholarship pertaining to the study of diversity and political participation.

The majority of studies on immigrant political participation in Canada define immigrants as those who are foreign-born. However, this definition is not universal with some scholars like Chui et al. (1991) focusing on multiple generations of immigrants, many of whom were born in Canada. Therefore, when possible, where immigrants have been defined as something other than foreign-born, this will be specified.

When considering immigrant political participation, it is of particular importance to distinguish whether immigrants have acquired Canadian citizenship. This is because certain forms of political participation are reserved exclusively for citizens such as voting in municipal, provincial and federal elections. Interestingly, it has also been suggested that citizenship acquisition, "may be a politically informative experience" and therefore, may be correlated with greater political engagement (Black 1982, 7).

It is well documented that immigrants in Canada have relatively high naturalization rates, with an estimated eighty-four percent of eligible immigrants having naturalized (Tran et al. 2005). Immigrants who are not Canadian citizens, however, can still be actively engaged in Canadian politics through less formal means like protest, lobbying and campaigning. Most existing literature makes this distinction between immigrant citizens and immigrant residents. 
Here, Figure 1 portrays the political participation of individuals living in Canada according to immigration status and naturalization. Native-born citizens are represented by the box labelled 'non-immigrants'. Those who are immigrants must first be further classified as either citizens or non-citizens when determining the overall scope of their political behaviours. Again, this is because the most formal types of participation, like voting, are exclusively reserved for citizens. As citizens, individuals whether immigrants or native-born, have a choice between voting and not voting as well as participating in other forms of less formal political engagement such as protest, campaign activity, contacting officials, lobbying or abstaining completely from politics. Non-citizens can also participate in these less formal manifestations of political participation.

Figure I: Formal and Informal Political Participation According to Immigrant Status and Naturalization

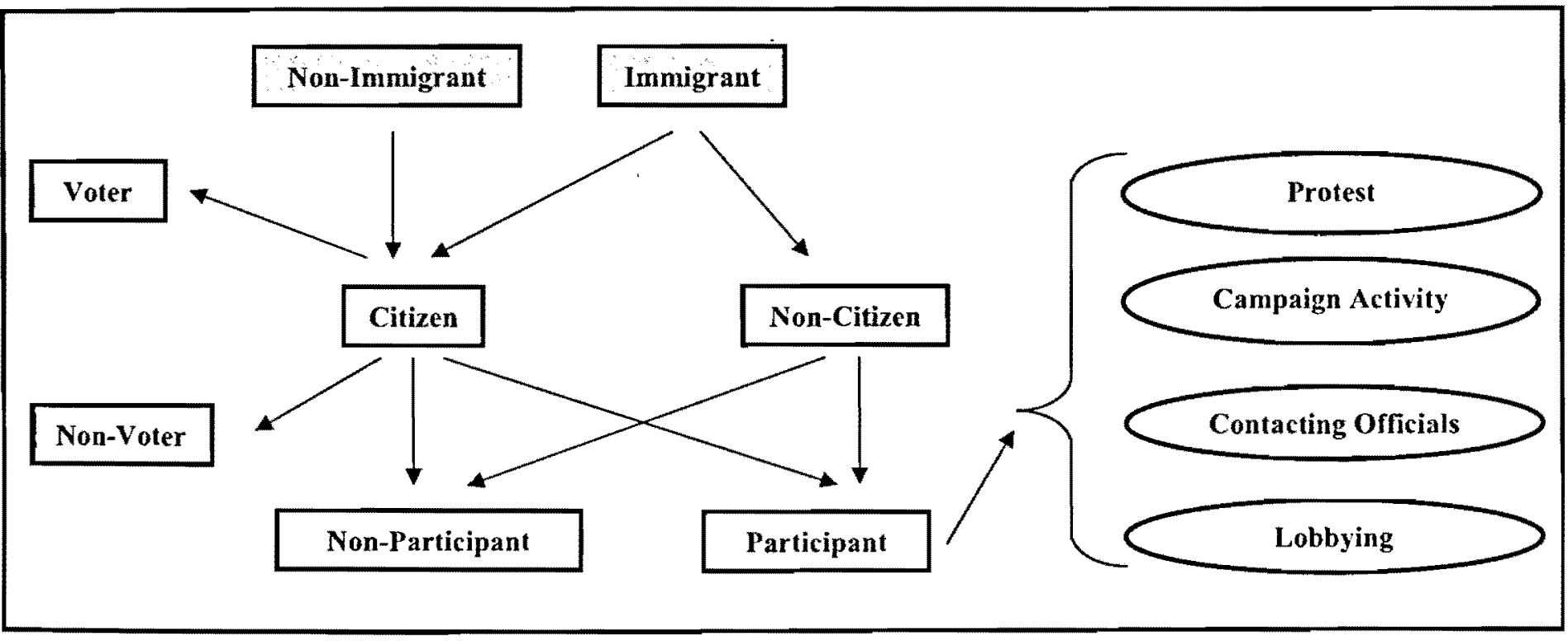

Adapted from Simpson Bueker $(2006,5)$ 


\section{DIVERSITY}

To begin, it is first necessary to determine how diversity creates context and how it is manifested within Canadian society, specifically at the neighbourhood level. The study of diversity has attracted the devotion of many scholars worldwide as people increasingly move across the globe. In fact, according to Thomas Faist (2009) the study of diversity is "in vogue" in both public debates and academic disciplines (171). Yet within the emerging literature, diversity is seldom defined while its implied meaning differs greatly from one scholarly source to the next. This section will evaluate how the existing literature frames diversity as a contextual effect. Again, in this review diversity refers to ethnic heterogeneity.

\section{DIVERSITY AS CONTEXT}

Raymond Breton (2005) notes that there are two main types of diversity, each of which can be interpreted as a determinant of context. The first is diversity resulting from segmentation which occurs when two or more groups are brought together, each with their own social and institutional systems. Commonly this type of diversity resulted from colonial forces. In Canada, this type of diversity is evident with English and French Canada where each has similar, but distinct institutions (5-6). The focus of this review is not this first type of diversity but it does provide a useful and relevant example of how diversity creates political context.

Accordingly, the context of 'segmentation diversity' in Canada has resulted in Québec having distinct institutions from the rest of Canada. This is the case for child care, immigration and the provincial pension plan (Lefebvre 2004; Black \& Hagen 1993). The political context of segmentation diversity, for example, played out in the Meech Lake Accord (1987) where the distinctiveness of Québec society and institutions were predominantly featured. Undoubtedly, the 
form of segmentation diversity founding Canada has been a great determinant of political context manifested in political debate, the separatist movement and tensions between English and French Canada.

It is worth noting that Aboriginals also fall under the auspices of segmentation diversity given that they also had their own distinct social and institutional systems (Breton 2005). Although many have been able to retain some of these social and institutional structures within the dominant Canadian nation-state, unlike in the case of the French in Canada, the context of this diversity led to limited rights. Still of importance is the fact that French Canadians and Aboriginals have maintained some of their social and institutional structures in Canada.

The second type of diversity, also found in Canada, is termed 'heterogeneity diversity' and denotes diversity resulting from the flow of migrants to Canada who do not choose or do not have the capacity to erect their own institutions. Instead, these migrants create their own communities which have both limited function and capacity (Breton 2005, 6-11). This type of diversity results from more recent immigration to Canada and is the focus of this review.

According to Breton (2005), these migrants will need to decide whether to become integrated into mainstream Canadian institutions or not (9). Recent work has also focused on how some ethnically specific characteristics, such as language, may prevent immigrant incorporation. However, integration or incorporation can also be defined as a "two way street", as is the theme of Biles et al. (2008) edited text whereby immigrants' incorporation must be the cumulative effort of both immigrants themselves and the Canadian state. As a result, diversity creates the context for Canadian policy which aims to educate and eliminate barriers that immigrants commonly face when integrating. 
Studies focussing on so-called 'contextual effects' examine how the characteristics of communities affect individual and group political activity. As suggested by David E. Campbell (2006), studies on contextual effects assume that one's actions are directly related to one's physical location (5). In other words, it is not only who but also where one is that influences their political behaviours.

Moreover, according to Eric Oliver (2001) the where that determines political behaviours does not mean that participating in politics is necessarily inherently different from one location to the next. Although there may be differences affecting the nature of political participation such as varying registration laws, the act of participating is for the most part similar across the United States, while the same can be said for Canada (23). Therefore, it is not merely participating from a given location that determines context since the location itself does not change the act of participating in politics. In other words, a Canadian citizen voting on a political matter in Richmond, British Columbia who then moves house and votes from Laval, Quebéc does not necessarily experience the process of voting as something unique to each location.

Instead the where indirectly influences the determinants of participation, meaning that it is the nature or characteristics of a given location which indirectly affects individual's political behaviours (Oliver 2001, 24). Determinants of participation can include such things as the social composition of neighbourhoods, population size, resources and economic conditions. In the case of the Canadian citizen voting first in Richmond and then in Laval, the individual characteristics of these communities such as whether resources are highly contested or whether there is the perception that others desire similar outcomes, may affect whether the individual participates in politics. Here, diversity creates context because it characterizes communities which can affect 
whether individuals participate in politics. This relationship will be further explored in this review.

\section{DIVERSITY WITHIN CANADIAN COMMUNITIES}

There is little question as to whether diversity exists in Canada. Over the past decade scholars like Myer Siemiatycki (2006) have utilized statistics to demonstrate that diversity has been increasing considerably. This phenomenon is not unique to Canada as ethnic diversity is increasing in most advanced countries (Faist 2009, 171; Putnam 2007, 138). According to Smith and Edmonston (1997), diversity on the whole has increased as the result of both direct immigration and immigrant residents having higher fertility rates than native-born populations (in Putnam 2007, 140).

In fact, the most recent 2006 Canadian Census revealed over 200 responses to ethnicity, highlighting the prevalence of ethnic diversity in Canada. Moreover, $16.2 \%$ percent of Canada's total population in 2006 were visible minorities. Notably, results from this same census also indicated that an average of twenty percent of the Canadian Population was foreign-born proving that immigrants represent a relatively significant proportion of the population.

Additionally, considerable scholarly attention has been devoted to the fact that this diversity tends to be concentrated in urban centres such as Toronto, Montréal and Vancouver. In particular Qadeer (2003) contends that Canadian cities tend to attract immigrants because of job and housing opportunities. Moreover, the existing concentration of immigrants living in cities can be a catalyst for increasing immigrant settlement to cities whereby immigrants may find comfort living amongst those who share a common language, culture and religion.

T.R Balakrishnan and Stephen Gyimah (2007) note that in 2001, ninety-four percent of immigrants who arrived during the 1990s were living in Canadian CMAs (313). In Montreal, one 
third of inhabitants are foreign-born whereas this number is one in five in Richmond, British Columbia. Toronto is Canada's most densely populated and diverse city, where half of all residents are foreign-born. Therefore, it is not entirely coincidental that the city has claimed "Diversity is our Strength" as their motto.

So what is the current context of neighbourhood diversity in Canada and how is diversity manifested at the community level? Due to issues of specificity, data on individual neighbourhoods is not available from Statistics Canada. Instead data on neighbourhood diversity can be derived from studies on CMAs and through more general measures of diversity including various indices.

As shown in Table 1, ethnic groups in Montréal are more consistently residentially concentrated than those in both Toronto and Vancouver. Jews are the most residentially concentrated ethnic group in Montréal and Toronto while South Asians in Montréal and Vancouver are also highly concentrated. Furthermore, Qadeer (2003) notes that the residential pattern of Jews in Toronto closely mirror racial segregation of Blacks in the United States.

Table 1: Gini Indices of Concentration by Ethnic Group for Montréal, Toronto, Vancouver, 2001.

\begin{tabular}{|l|l|l|l|}
\hline Ethnic Group & Montréal & Toronto & Vancouver \\
\hline British & 0.442 & 0.375 & 0.315 \\
\hline French & 0.304 & 0.380 & 0.330 \\
\hline Italian & 0.580 & 0.550 & 0.411 \\
\hline Jewish & 0.895 & 0.814 & 0.586 \\
\hline South Asian & 0.809 & 0.593 & 0.629 \\
\hline Chinese & 0.675 & 0.635 & 0.569 \\
\hline Western European & 0.421 & 0.388 & 0.319 \\
\hline $\begin{array}{l}\text { Central and Eastern } \\
\text { European }\end{array}$ & 0.502 & 0.360 & 0.264 \\
\hline African & 0.587 & 0.541 & 0.444 \\
\hline Caribbean & 0.646 & 0.518 & 0.494 \\
\hline
\end{tabular}

Data from Balakrishnan and Gyimah $(2007,319)$. 
Table 1 also shows that other ethnic groups including French, English, Eastern Europeans, Northern Europeans, Western Europeans, Italians, Chinese, Caribbean and Africans are not residentially concentrated. Overall, the Gini Index demonstrates a general trend of residential diversity in Canada where, with few exceptions, ethnic groups are not highly concentrated. This implies that diversity characterizes patterns of settlement in Canada.

As a measure of diversity, the Gini Index shows the spatial concentration of ethnic groups residing in a particular location. This Index is based on the Lorenz Curve whereby the vertical axis marks the cumulative percentage of an ethnic group's population. The horizontal axis represents geographically defined areas, commonly census tracts, arranged in descending order of largest to smallest ethnic populations. The further the curve is away from the diagonal, the greater the ethnic concentration of a given ethnic group. Here, a range is computed between 0 and 1, with 1 representing complete concentration (Gastwirth 1972).

Alternatively, community diversity can also be characterized through looking at the percentage of census tracts in which either fifty or ninety percent of an ethnic population concentrate. As shown in Table 2, overall ethnic concentrations are not characteristic of the whole of Montréal, Toronto or Vancouver. The exception to this, also suggested by the Gini Index, is Jews in Montréal and to a lesser extend Toronto. South Asians also tend to have higher concentrations than other ethnic groups with British and French having the most dispersed residential settlement patterns. 
Table 2: Percentage of Census Tracts in which $50 \%$ and $90 \%$ of Ethnic Population are Concentrated, Montréal, Toronto and Vancouver, 2001.

\begin{tabular}{|c|c|c|c|c|c|c|}
\hline \multirow[b]{2}{*}{ Ethnic Group } & \multicolumn{3}{|c|}{$\begin{array}{l}\text { Percentage of Census Tracts in } \\
\text { which } 50 \% \text { of Ethnic Population is } \\
\text { Concentrated }\end{array}$} & \multicolumn{3}{|c|}{$\begin{array}{l}\text { Percentage of Census Tracts in } \\
\text { which } 90 \% \text { of Ethnic Population } \\
\text { is Concentrate }\end{array}$} \\
\hline & Montréal & Toronto & Vancouver & Montréal & Toronto & $\begin{array}{l}\text { Vancouv } \\
\text { er }\end{array}$ \\
\hline British & 19.7 & 25.4 & 29.3 & 71.4 & 70.0 & 73.3 \\
\hline French & 29.8 & 25.3 & 28.5 & 74.7 & 68.7 & 72.8 \\
\hline Italian & 12.3 & 13.6 & 23.1 & 55.9 & 60.6 & 68.7 \\
\hline Jewish & 2.4 & 3.8 & 14.3 & 13.6 & 26.2 & 51.0 \\
\hline South Asian & 4.6 & 13.7 & 10.4 & 27.2 & 50.1 & 50.0 \\
\hline Chinese & 9.1 & 10.2 & 10.6 & 42.4 & 50.6 & 50.3 \\
\hline Western European & 21.0 & 24.5 & $29 . \overline{3}$ & 68.1 & 68.7 & $72 . \overline{8}$ \\
\hline $\begin{array}{l}\text { Central and Eastern } \\
\text { European }\end{array}$ & 17.8 & $\overline{26.0}$ & 32.4 & $60 . \overline{4}$ & 72.4 & 76.7 \\
\hline African & 14.15 & $15 . \overline{9}$ & 22.5 & 50.2 & 57.4 & 63.0 \\
\hline Caribbean & 11.5 & 17.4 & 20.2 & 44.7 & 57.5 & 57.5 \\
\hline $\begin{array}{l}\text { Total Census } \\
\text { Tracts }\end{array}$ & 846 & 924 & 386 & 846 & 924 & 386 \\
\hline
\end{tabular}

Data from Balakrishnan and Gyimah (2007,317).

The percentage of census tracts in which both fifty and ninety percent of ethnic populations are concentrated demonstrate that British, French, Italian, Chinese, Western European, Central and Eastern European, African and Caribbean are ethnically dispersed across Canada's three largest cities. Again as with the Gini Index, this suggests a general trend of ethnic diversity. If the percentages were higher, then ethnic groups would be more residentially segregated, showing a reverse trend away from diversity. This finding further strengthens the need for studies on diversity. 


\section{POLITICAL PARTICIPATION}

When considering political participation, there are many factors which may inhibit or promote participation rates. Existing studies have traditionally focused on the role of political socialization, rational choice models and so-called 'facilitative' and 'motivational' factors. This includes interest in and exposure to politics as well as the impact of demographic characteristics such as income and education on political participation. It is worth noting that these models have been conventionally utilized to determine voting behaviours, as will be outlined in this review, but can be extended to other forms of political participation.

\section{TRADITIONAL MODELS OF POLITICAL PARTICIPATION}

Political socialization models, represented in the first box in Figure 2, invoke the classical thought of theorists like Plato, Aristotle and Rousseau all of whom emphasized the nature of man, drawing particular attention to the psychological underpinnings of man's civic socialization and subsequent participation in politics (Hyman 1969, 2). Utilizing a psychological approach, political scholars stress the importance of socialization as a mediator through which individuals learn their political behaviours (Langton 1969, 5). Here political socialization refers to the process through which individuals learn their political behaviours:

Political socialization is the process of induction into the political culture. Its end product is a set of attitudes- cognitions, value standards, and feelings- toward the political system, its various roles and role incumbents. It also includes knowledge of, values affecting and feelings towards the inputs of demands and claims into the system, and its authoritative outputs (Almond 1960, 27-28).

Political socialization typically involves a stimulus from school, parents, family, friends and the media, all of whom shape individual's political behaviours. 
According to the political socialization model, it is assumed that when individuals are taught to participate, they will be more likely to engage in political action. Additionally, the process of socialization can also entail the learning of social norms, including the civic duty to vote or participate in political actions. From a broader national perspective, André Blais (2000) reveals that in one of every five democratic countries, laws detail voting in national elections not only as a right but also as a duty (92). As part of citizen's socialization from the state, this ultimately reinforces the idea that notions of voting as a duty can be part of the political socialization process whereby laws can induce certain values.

Alternatively, rational choice models, shown in the second box in Figure 2, deal with the "expected utility associated with outcomes" and assume that individual's calculated preferences induce their actions (Aldrich 1993,248). Ultimately, it is assumed that individuals assess costs and benefits when choosing whether to participate in politics and will abstain from voting when the costs outweigh the benefits. For example, when an individual's preferred candidate has little chance of winning there is less incentive for them to vote.

Although this theory has become increasingly sophisticated over time through numerous amendments, rational choice models have come under great scrutiny with some scholars claiming that the theory suffers methodologically, that benefits never really outweigh the costs, and that human behaviours cannot be understood or characterized by a single equation (Green \& Sharpio 1994). Despite this, Riker and Ordeshook (1968) contend that political participation is a rational behaviour when individuals receive some sort of gratification from voting. Therefore, a 
more recent rational choice model can be expressed as:

$$
\mathrm{R}=\mathrm{PB}-\mathrm{C}+\mathrm{D}
$$

where $\mathrm{R}$ indicates the rewards which an individual receives from voting and essentially the overall likelihood of this person voting, $\mathrm{P}$ is the probability that an individual casts the decisive vote in the given election, B indicates the benefits associated with the election of one's preferred candidate, D represents the voter's gratification from voting and C is the cost associated with voting.

Ultimately, when the rewards are great enough then it is within an individual's interest to vote. The D value is a particularly important addition from Riker and Ordeshook (1968) because it connotes personal satisfaction derived from voting which includes gratification from fulfilling one's civic duty to vote. Otherwise, it is highly contested whether that the benefits of voting actually outweigh the costs especially since the $P$ value is always very small. Again, the $D$ value also represents an essential element of the political socialization model and arguably, a key feature determining why individuals vote.

On the other hand, Lester Milbrath (1971) made the distinction that, "Casting a vote... may be primarily expressive in one situation for one person but primarily instrumental for another situation or person" (29) indicating that there may be other facilitative and motivational factors affecting individual's behaviours to participate in politics. Facilitative factors, shown in the third box of Figure 2, are those individual variables and aspects of institutional settings that either facilitate or hinder political participation. Here, it is assumed that individual's political behaviours vary because it is more difficult for some to participate than others (Oppenhuis 1995). 
Individual variables commonly include socio-structural aspects of life such as income, education, age and marital status. Moreover, both a high income and advanced education tend to be positively correlated with political participation (Oppenhuis 1995; Verba et al. 1995; Verba \& Nie 1972). In the Canadian context, there is also a very strong generational effect whereby, the decade in which one is born is a good indicator of whether they will participate in politics or not. Moreover, generational effects have most recently been attributed to differences in values and beliefs (Rubenson et al. 2004).

Institutional settings can also increase or decrease the likelihood of individual's political engagement. Registration laws and electoral systems can, for example, facilitate or hinder voting. Similarly, limiting elections from being held on weekends can lead to the inclusion of some religious groups who would otherwise likely abstain from voting.

Motivational factors affecting individual's political behaviours, represented in the fourth box in Figure 2, are more psychological in nature and include political attitudes and orientations. Here, individuals with a keen interest in politics will be likely to vote in elections whereas, those who have little interest will be less likely to participate.

Similarly, if an individual feels a strong affinity to a candidate or political party they may be more likely than those who are indifferent to cast a ballot. Political mobilization is also considered a motivational factor and in instances where communities or individuals are encouraged by candidates to become politically engaged, it is generally more likely that they will do so (Rosenstone \& Hansen 1993). This model may also account for social norms whereby participation is motivated by one's civic duty to vote. 
Figure 2: Summary of Traditional Models of Political Participation

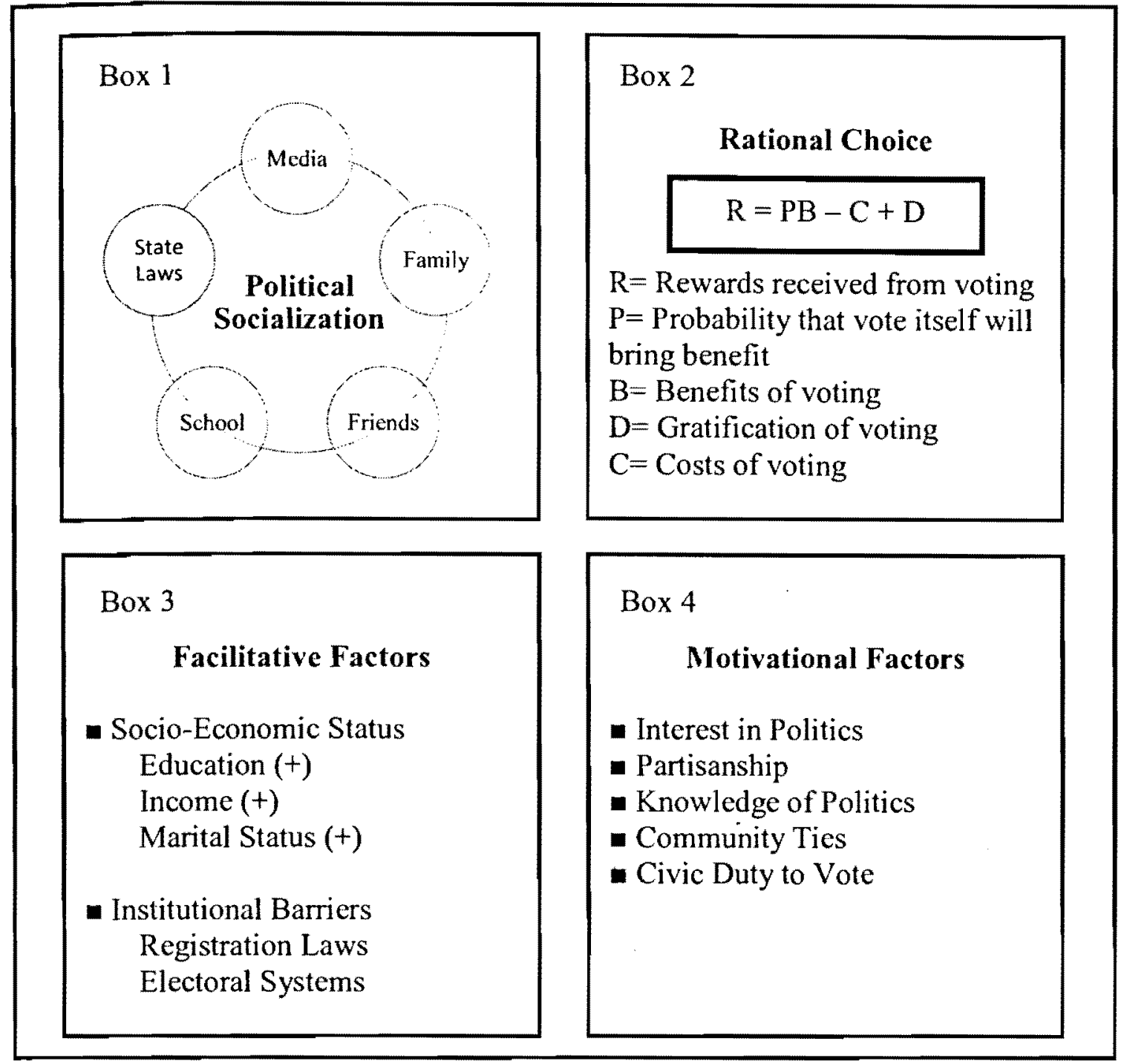

Adapted from Ramakrishnan $(2005,73)$

According to Karthick Ramakrishnan (2005), however, some contemporary studies suggest that traditional models of political participation fail to adequately explain immigrant political behaviours. In particular, facilitative factors such as socio-economic status have received the brunt of criticisms. Moreover, Cho (1999) asserts that socio-economic theories fail to adequately explain political behaviours within immigrant minority communities because 
although individual variables like income, education and age provide essential skills necessary for political participation, it is ultimately socialization which determines how skills are utilized.

For example, contrary to what is traditionally assumed about age in the socio-economic model, it is not merely growing old which increases an immigrant's likelihood to vote but rather the amount of time they have lived in their new country. In her study of minority groups in Califormia, United States, Cho (1999) found that age was negatively related to voting for Asian and Latinos, suggesting what Ramakrishnan has termed "immigrant exceptionalism", indicating that common indicators are not always applicable to immigrants. Despite the validity of this claim, it is necessary to acknowledge that Cho's assertions are based on considerably older data, looking at a single point in time which makes it difficult to generalize.

What is particularly interesting about the contention that traditional models are not suitable for predicting immigrant political behaviours is the fact that all other models discussed, including political socialization, rational choice, and motivational factors can easily be adapted to include immigrants in their analysis. The difference, however, appears to be that with the exception of political socialization, models are not tailored to extrapolate or highlight the unique circumstances immigrants may face when entering the realm of Canadian politics. Similarly, with the exception of modified versions of political socialization and motivational factors, other models have not generally been utilized by scholars studying immigrant political participation.

Political socialization models have been widely adapted and applied to immigrants as a means for better understanding their political behaviours (see Black 1987; White et al. 2008). In fact, models developed for the sole purpose of determining immigrant political participation have been largely based on more traditional political socialization models. As will later be discussed in this review, political transferability is one such model which examines whether certain aspects 
of political socialization are transferable from an immigrant's country of origins to their new destination country.

Rational choice models can also address immigrant political behaviours through acknowledging the various barriers immigrants face by accounting for these as costs. Albeit, it may be particularly difficult to know all costs, making it more complex to calculate how overall benefits can be maximized and costs minimized. These barriers, like the inability to read or speak English or French, however, in many instances remain unique to immigrants which does imply that rational choice models are not specifically designed to account for differences between foreign-born and native-born citizens.

Motivational factors also have a particular role in determining immigrant political participation. Specifically, mobilization directed towards immigrant and ethnic groups can increase knowledge and lead to interest in politics. Existing studies on how motivational factors affect immigrant political behaviour in Canada remain limited making it difficult to determine whether such models are well suited for understanding immigrants' political behaviours. Yet one can speculate that it is likely that ethnic communities play crucial roles in either motivating or discouraging the political behaviours of their members.

Therefore, it may not be completely valid to claim that traditional models fail to account for immigrant political behaviour. Instead, it appears that some models like political socialization are more suitable than others like socio-economic status. What is particularly interesting about these models is that none really account for community context which is something that immigrants themselves are changing in their ethnic composition. As will later be explored, a contextual model would be of benefit to determine how the presence of immigrants and the subsequent diversity they create affects political behaviours. 


\section{OVERVIEW OF STUDIES ON IMMIGRANT POLITICAL PARTICIPATION}

It is particularly useful to address why immigrant political participation ought to be

highly valued and why it must be evaluated separately from other citizens. The simple answer is that immigrant political participation is crucial for both immigrants and the greater Canadian polity. In fact, immigrant voting has traditionally been an indicator of immigrant integration and incorporation within the Canadian state and thus, is the desired outcome of immigrant settlement (Saloojee 2002). Scholar Jean Tillie (2004) notes that there are three distinct forms of immigrant political integration including trust in government institutions, adherence to democratic values and political engagement (530). This review is interested in the latter but also explores trust as a facilitator of voting.

Of particular importance to immigrants, Jorge Ginieniewicz (2007) contends that voting by Latin American immigrants in Canada:

is crucial to gain space, make the community more visible, influence the allocation of human and economic resources as well as put forward an agenda that would deal with issues that have a direct impact on the daily life of members of the community such as high rates of school dropout, poverty and the validation of professional credentials (328).

This statement is also applicable to other immigrant groups, many of whom benefit greatly from becoming politically engaged. In his study on the political participation of immigrants in the United States, Ramakrishnan (2005) also emphasizes the relationship between political participation and the economic advancement of immigrants, specifically in the housing market and workplace.

Bilodeau and Kanji (2006) also echo this sentiment, noting that more recent immigrants to Canada come from different source countries than before and therefore, it is reasonable to assume that newer immigrants may have different or distinct needs from the rest of Canadian society. Accordingly, these needs may not be addressed unless immigrants have their voices 
heard through their subsequent participation in Canadian politics. Similarly, originating from the literature on the United States is the growing concern that the disenfranchisement of certain ethno-racial groups will lead to the "political equivalent of an economic underclass" which can similarly be extended to the case of Canada (Simpson Bueker 2006, 3). Concerning voting, both who votes and who does not vote may greatly influence who is elected, what policies are enacted and how resources are allocated.

Earlier studies on immigrant political participation in Canada suggested that immigrants participated less than Canadian-born. The first of these studies by Anthony Richmond and John Goldlust (1977) found that activity in political organizations was lower for immigrants of Greek, Portuguese, Asia and Black descent compared to Canadian-born (52). This finding led to further studies looking at why such differences were apparent.

An attempt was then made by Jeffrey Reitz (1980) to better understand why immigrant political participation, measured by voting, attendance at political meetings and familiarity with public affairs, was lower than that of Canadian-born. Reitz's study found that political participation rates were related to immigrant's ethnic identities suggesting that ethnic cohesion hindered immigrant political participation. Accordingly, "Those who retain strong ties to an ethnic group are less likely to participate in Canadian politics than those who have abandoned such ties" (227). This finding, however, would subsequently be contested.

John Wood's 1981 publication focusing on political participation in the Vancouver area drew a dichotomous distinction between the political behaviours of East Indians and Non-East Indians. In contrast to earlier research, Wood's findings revealed that there were negligible differences in political participation between the two groups. Here, political participation was measured by voting in the 1974 federal election, interest in politics and political efficacy. 
Supporting this assertion, Jerome Black (1982) similarly found no significant difference between the rates of political participation for immigrants and Canadian-born based on data from the 1974 Canadian Election Study (14).

Black's study considered multiple measures of participation, including voting and campaigning, increasing the validity of his finding that no differences were apparent between the participation rates of Canadian-born and immigrant. The publication of this study was significant, even groundbreaking, changing the way in which immigrant political participation was viewed. Future studies would build upon Black's concluding remarks which speculated why immigrant political participation was at parity with Canadian-born levels.

In another related study by Black (1991), based on Toronto survey data, he found that when differences were apparent between immigrant and Canadian-born political participation rates, that through controlling for length of residence, differences would dissipate. Black's measures of political participation included voting, campaign activism, communal activity and contacting officials. This finding held true after controls were introduced for socio-economic status, partisanship, efficacy and political interest. Here, length of residence accounted for differences in political participation and not strong ethnic identities as previously suggested by Reitz (1980). Thus, Black concluded that as immigrants become more established and have greater exposure to Canadian politics and norms, they participate as much as Canadian-born in politics.

Research focusing on the settlement of immigrants in Canada makes the related point that upon arrival, immigrants often must first secure appropriate housing, jobs and resources before they can participate in politics. Chui et al. (1991), studying political participation across generations, found that participation was low amongst first generation Canadians, suggesting that 
economic survival, finding a job, securing housing and learning English all impeded one's ability to participate. Political participation, however, peaked for second generation Canadians, indicating that participation is not necessarily higher for more established immigrant families in Canada. In this study, multiple measures of political participation were utilized including political group membership and interest in politics. Those measures yielding statistically significant results were campaigning, contacting politicians and voting.

The underlying assumption about resources is also pivotal in Verba et al.'s renowned political research (1995) where resources ultimately enable political participation. In an earlier publication, Verba et al. (1993) found that resources alone, including education, time, money and language, could account for differences in the political participation of African-Americans, Latinos and Anglo-Whites in the United States. In this study, political participation included voting, campaigning, making financial contributions to political parties, contacting officials, protesting and joining a political organization. In the Canadian context, it also appears true that resources play a crucial role in determining whether immigrants are politically engaged.

In a 1987 study, Black also brought to the forefront the issue of 'political transferability' which is chiefly concerned with determining whether immigrants from non-traditional source countries, many of whom never lived under a democratic regime, could translate their past political experiences to participation in Canadian democracy. The assumption behind this hypothesis is that immigrants can become politically integrated so long as their skills are 'transferable'. Significantly, this study revealed that political transferability occurs not only amongst British immigrants but also Non-British immigrants implying that all immigrants can draw upon their past political experiences in order to participate in Canadian politics. 
Verba et al.'s (1995) contributions to the literature on civic engagement also suggest that skills like communication and organization can be utilized in political engagement. Given that these skills are possessed by individuals, they also move during the process of migration. Thus, political skills can also be transferable and may enable immigrants to become better politically integrated. Some skills, however, may be more relevant than others which could explain variances in why some immigrants participate in Canadian politics while others do not.

Other studies have been conducted on the political socialization of immigrants related to Black's initial conception of political transferability. White at al. (2008), for example, test three distinct hypotheses on how immigrants are socialized politically, each with implications for immigrant political participation in Canada. In this study, political participation was measured by voter turnout, campaigning and interest in federal politics.

The first hypothesis, for which they find limited evidence, makes the assertion that older immigrants will be resistant to change and consequently are more likely than younger immigrants to abstain from integrating politically and subsequently participating in Canadian politics. In a related study, through interviewing refugees from Laos, John Harles (1997) found that political socialization mainly took place in Canada. In fact, a lack of political socialization best characterized the socialization process in the home country given that multiple respondents noted that politics were not discussed or taught in the home (724). Harles demonstrated that immigrants from Laos were generally keen to vote in Canadian elections, directly challenging the premise that older immigrants can't be resocialized.

The second hypothesis by White et al. (2008) is directly related to Black's political transferability theory (1987); however, here the evidence is less clear. It is important to note that much of the data on political transferability theory dates back to the 1980 s when immigrants in 
Canada came from very different countries of origin. It would be of particular interest to categorize immigrants specifically by regime type in order to identify how an immigrant's country of origin may affect their ability to transfer political skills. The dichotomous categorization of 'British' and 'Non- British', initially utilized by Black (1987) is arguably now outdated given the realities of who immigrates to Canada and prevents one from analyzing the full spectrum of political regimes.

More recent contributions have also been made to the literature on how pre-migration regimes affect immigrants' likelihood to participate in political protests. Of course, protest as a form of political participation can also be transnational in nature, making it more difficult to draw conclusions on political integration. Through a comparative study of immigrants from across the globe, Bilodeau (2008) found that immigrants migrating from countries with repressive regimes were less likely to participate in political protests than those immigrants originating from countries with non-repressive regimes. Here, the effect of political socialization in an immigrant's country of origin was dominant.

Moreover, Bilodeau (2008) discovered a correlation between the degree of repression in an immigrant's home country and how much an immigrant participates in protest politics in Canada. In this instance, Bilodeau's work supports White et al.'s first hypothesis (2008) that assumes political socialization mainly occurs at a relatively young age and thus tends to occur in an immigrant's country of origin. Furthermore, Bilodeau contends that even after thirty years of living in Canada, immigrants who migrated from countries with repressive regimes were still likely to abstain from protest politics. This would also directly challenge Black's earlier work $(1987 ; 1991)$. Bilodeau's findings are applicable not only to the case of Canada but also Australia, increasing its validity. 
The third hypothesis tested by White et al. (2008) claims that the more immigrants are exposed to Canadian politics, the more likely they are to participate. This hypothesis garners the most support, drawing the conclusion that the longer immigrants are exposed to political stimuli in Canada, the more likely they are to participate. The ethnic media and community leaders are also believed to augment political exposure, ultimately speeding up the process of political integration and encouraging immigrant political participation.

The role of the ethnic media has also been examined in Canada to determine whether it hinders the participation of immigrants in Canadian politics. Black and Leithner (1988) failed to find evidence supporting this assertion, suggesting that if anything, the ethnic media provides relevant political information to new Canadians which could increase immigrants' political participation. Conversely, Lapp (1999) examined ethnic leaders from Jewish, Italian, Greek, Portuguese and Chinese communities in Montreal during the 1993 federal election and the 1994 municipal and provincial elections, finding that ethnic community leaders had a limited impact on voter turnout.

Lapp's study (1999) also revealed differences in voter turnout between different ethnic groups. For example, Jewish and Chinese had relatively lower voter turnout whereas, the Greek community had higher than average voter turnout. Members of the Italian and Portuguese ethnic community had average turnout rates which were comparable to overall Canadian voter turnout. In fact, newer studies focusing on particular ethno-cultural immigrant groups in Canada reveal that not all immigrants participate as much or as little as Canadian-born (Jedwab 2006).

Instead, more contemporary research reveals that immigrants born in European countries tend to have higher political participation in Canada than those originating from non-European countries. Particularly, immigrants born in Asia, the Middle East and Latin America have 
relatively lower participation rates (Jedwab 2006). This finding doesn't necessarily indicate fallacies with earlier research conducted in the 1980s since immigrants in Canada were commonly from more traditional European countries than they are today.

Therefore, older research may be misleading when considering the immigrants of today since it appears that immigrant political participation changes with migrant flows and more specifically, depends on where immigrants originate from. As immigrants from different source countries settle in Canada, further studies are needed. Yet, despite these differences between immigrant groups, research still suggests that on a whole immigrants participate as much, or as little as Canadian-born in Canadian politics (White at al. 2006; Gidengil et al. 2004).

Figure 3 provides a summary of the political participation models discussed above which are utilized to understand immigrant political behaviours. Most recently, it appears that efforts have been shifted towards understanding models derived from political socialization whereby political learning is central. With the exception of Reitz's (1980) ethnic cohesion model, which has since been disproven, immigrant status, political transferability, political socialization and political exposure all provide useful accounts of immigrant political behaviours. One of the shortcomings of these models, however, is that none adequately account for differences within immigrant ethnic groups. 
Figure 3: Summary of Immigrant Political Participation Models

\begin{tabular}{|c|c|c|}
\hline $\begin{array}{l}\text { Ethnic Cohesion } \\
\qquad \text { Reitz (1980) } \\
\text { - Loyalty to one's culture } \\
\text { prohibits political participation }\end{array}$ & $\begin{array}{c}\text { Immigrant Status } \\
\text { (i.e. length of residence) } \\
\text { Black 1991; Chi, Curtis \& Lambert } \\
\text { (1991) } \\
\text { - Once basic needs have been } \\
\text { met (securing food, shelter, } \\
\text { work, language, etc.) immigrants } \\
\text { can start to participate in politics }\end{array}$ & $\begin{array}{l}\text { Political Transferability } \\
\text { Black (1987); White, Nevitte, Blais, } \\
\text { Gidengill, \& Fournier (2008); Bilodeau } \\
\text { (2008) } \\
\text { - Immigrants transfer beliefs } \\
\text { and behaviours from one } \\
\text { political system to another and } \\
\text { therefore can draw upon political } \\
\text { skills developed in a different } \\
\text { environment }\end{array}$ \\
\hline $\begin{array}{l}\text { Political Socialization } \\
\text { Black (1987); Harles (1997); Bilodeau } \\
\text { (2008); White, Nevitte, Blais, Gidengil } \\
\text { \& Fournier (2008) } \\
\text { - How immigrants are socialized } \\
\text { (whether in Canada or abroad) } \\
\text { can determine whether they } \\
\text { participate in Canadian politics }\end{array}$ & $\begin{array}{l}\quad \text { Political Exposure } \\
\text { Black \& Leithner (1988); Lapp (1999); } \\
\text { White, Nevitte, Blais, Gidengil \& } \\
\quad \text { Fournier (2008) } \\
\text { - Exposure to Canadian politics } \\
\text { can encourage immigrant } \\
\text { political participation. } \\
\text { Similarly the ethnic elite and } \\
\text { media can serve as } \\
\text { intermediaries, transmitting } \\
\text { political information to } \\
\text { immigrants }\end{array}$ & \\
\hline
\end{tabular}

Related to the wider body of literature, some scholars have stated their concern with the methodology of both older and newer studies on immigrant political participation. Anderson and Black (2008), for example, contend that employing a dichotomy of 'immigrant' and 'Canadianborn' participation is more indicative of Canadian-born rates, which don't serve as ideal benchmarks for political participation given that Canadian political participation rates have been declining and remain relatively low (47). Supporting this assertion, Jack Jedwab (2006) makes the crucial point that this same dichotomy tends to mask the fact that there are differences in the 
political participation of immigrants from different ethno-racial backgrounds. However, it appears that at the moment, few alternatives have been advanced for studying immigrant political participation.

Again, this review will explore the existing literature suggesting the utilization of a social capital model for better understanding the political behaviours of citizens. This model can also be utilized to better understand why some immigrants participate while others do not. Given the basic assumptions of this model, it can also be applied to Canadian-born but is of particular interest to immigrants, given that immigrants themselves foster diversity, which is central to understanding the context of political engagement.

\section{SOCIAL CAPITAL: LINKING POLITICAL PARTICIPATION AND DIVERSITY}

Social capital theorists have been keenly interested in political participation, the usefulness of social networks and the transferability of civic skills as a means of increasing participation rates (Putnam 1993, Verba et al. 1995). Such theorists have attempted to explain participation rates according to the strength of civic society. Similarly, social capital theorists have made particular observations on how the diversity of neighbourhoods affects social networking. By combining these studies and their application of social capital theory one can better explain the relationship between community diversity and voting.

Social capital is a factor in the relationship between community diversity and political participation because it is a community resource which structures relations between individuals (Rubenson 2005). Here, it is of particular importance to relate social capital theory back to original research question. Essentially, what must be evaluated is how social capital is related to both diversity and political participation. In other words, how does diversity condition social 
capital? and how does social capital impact political engagement? These questions are related to the larger question of how social capital can explain how context affects individual's political behaviours within diverse settings.

\section{SOCIAL CAPITAL AS THEORY}

Arguably, the concept of social capital dates back to the $19^{\text {th }}$ century to the writings of French historian Alexis de Tocqueville (1835) who identified what was later termed 'social capital' by arguing that, "the more individuals get used to the idea of coming together for economic, social or moral purposes, they enhance their capacity to pursue great undertakings in common" (110). Although social capital theory is commonly associated with the acclaimed works of French sociologist Pierre Bourdieu (1986), social capital became popularized within political discourse in the early 1990s with the publication of Robert D. Putnam's Making Democracy Work (1993).

Conceptualizations of social capital differ greatly within academia as do the ascribed benefits. According to political scientist Dietlind Stolle (2003), social capital is a societal resource which links citizens to each other, enabling them to pursue common objectives more effectively. Therefore, social capital results from the willingness of citizens to cooperate with each other and to engage in civic endeavours collectively. Arguably, the most referenced and renowned scholars on social capital theory are Bourdieu, Coleman and Putnam.

Considering social capital, Bourdieu (1986) claims that social relations become 'capital' through the reproduction of personal relationships (248). Bourdieu believes that social capital emphasizes individual gains and not necessarily those of a greater community. In this instance, social capital is useful for better understanding the production of inequalities whereby some 
individuals use their relations with others to gain more power for themselves. This interpretation of social capital has been further expanded in game theory but arguably has a limited application to political participation.

According to Baron et al. (2000), James Coleman $(1988,1990)$ was the first academic to attempt to empirically quantify and measure social capital. Coleman's (1990) conceptualization of social capital relies heavily upon the importance of social structures meaning that the structure of relationships between individuals determines outcomes. Also, according to Coleman (1990), "social capital is defined by its function" (302) which has drawn criticism from Teorell (2000, 2) who argues that this definition is problematic because social capital cannot be proven to exists if it cannot be shown to have a causal effect.

Putnam (1993) defines social capital as the "features of social organizations, such as trust, norms and networks that can improve the efficiency of society facilitating coordinated actions" (167). This definition suggests that certain aspects of social relations are particularly conducive to facilitating social capital. Rubenson (2005), however, contends that Putnam's definition "confuses issues of definition with those of empirical investigation" (5) because it defines social capital both in terms of its cause and effect.

Furthermore, social capital is not merely the manifestation of social organizations but rather refers to how the structures of relations between individuals facilitate action. Therefore, obligations, expectations, information channels as well as other aspects of social relations may further characterize social capital (Coleman 1988). Accordingly, this literature review takes the position that trust, norms and networks produce social capital and that social capital generates tangible benefits which are the direct result of societal relations. At present, there doesn't appear 
to be adequate empirical evidence supporting the assertion that trust, norms and networks are actually produced by social capital.

Issues surrounding how best to define social capital have undoubtedly created difficulties in terms of measuring the concept. Consequently, scholars tend to measure social capital according to those pre-identified features of human relations including trust, norms, social networks, obligations and information channels. Yet, what remains crucial is that social capital is not merely the measure of each, but rather a cumulative reflection of multiple measures, all representing the structure of relations between individuals.

\section{SOCIAL CAPITAL AND NORMS}

The contextual model for immigrant political participation featured in this literature review follows some very specific logic: that citizens, including immigrants, vote because voting is a civic duty. This model makes the central assumption that individuals vote in order to adhere to social norms. Accordingly, what interests scholars about immigrant political participation is how diversity within communities affects the exchange and inculcation of normative behaviours like voting.

Social norms have received a great deal of academic attention by scholars from economists to anthropologists. Although some scholars define norms very narrowly, other definitions have been more open to interpretation. According to Cialdini and Trost (1985), "social norms are rules and standards that are understood by members of a group, and that guide and/ or constrain social behaviour without the force of laws" (152). Yet despite this recent attention from scholars, little is known about how norms form and how they relate to individual's values (Fehr \& Fishbacher 2004, 64). 
Deviance from social norms is typically associated with individuals' embarrassment, anxiety, shame and guilt. At the community level deviance is often met with sanctions from societal networks. In fact, Coleman (1990) emphasizes that norms exist only when one can control other's actions (243). Norms for sanctioning those who fail to adhere to social norms have even been termed 'meta-norms' by Axelrod (1986), demonstrating the mere prevalence of social norms in society. Furthermore, Fehr and Fishbacher (2004) found that individual members tend to enforce norms even when doing so is costly.

Stephen Knack (1992) contends that social norms can help explain why married people tend to vote more than those who are widowed or single, emphasizing the importance of norms on political participation (139). Referencing a 1983 survey, Knack also reinforces the idea that most Americans believe that people ought to vote and that voting is a social norm. $\ln$ such instances both expectations and sanctions motivate political action. Blais (2000) provides a similar finding in his study of Canadian university students during the 1993 federal election where $43 \%$ of respondents strongly agreed that voting is a civic duty (95).

Elster's (1989) distinction between rational choice models and social norms better illustrates how social norms are manifested. Elster claims that the most basic manifestation of social norms is "do $\mathrm{x}$ or don't do $\mathrm{x}$ ", implying that individuals have a choice between following or deviating from social norms. Illustrating a more complex situation, social norms can also be present when "if others do $x$ then do $x$ ". Lastly, emphasizing the common good associated with social norms one may "do $x$ if it would be good if everyone did x" (99). Applied to voting, norms can be understood as vote or don't vote but there will be consequences, if others vote then vote and follow the social norms, and if it would be good for everyone to vote, then vote. 
Cialdini and Trost (1985) also contend that in order for social norms to persist three main conditions must be met. These conditions are of particular interest to the model given their overall relevance and the likelihood that diversity impacts each community uniquely. First, communication must occur freely between members of the given social group allowing nonms to be transmitted. Second, the group must be a cohesive unit so as to allow sanctions to be meaningful. Lastly, the norm must be important to the group and must serve a useful purpose (152).

In the case of political participation, norms tend to be manifested in a sense of duty to vote which serves a clear purpose to the group. The question remains, however, regarding the first and second condition, how diverse communities transmit social norms and how cohesive groups can be when group members are from different ethnic backgrounds. Norms have traditionally been thought to be culturally specific and therefore, it is possible that people from different cultural and ethnic backgrounds may not share the same civic duty to vote.

It is worth noting that there may in fact be other incentives, in addition to gratification associated with following social norms, which motivate group members to participate in politics. In response to criticism surrounding rational choice models and emphasis placed on self-interest, James Fowler (2006) suggests that individuals may actually choose to vote with the intention of providing benefits to others instead of themselves. Accordingly, individuals may act out of "social identification" meaning that they vote with the intention of benefiting the welfare of a certain group of people or alternatively out of "altruism" meaning that they believe that their actions will bring good to all (Fowler \& Kam 2007, 813- 814).

Although Fowler's work defines groups by partisanship, this same logic may also help explain the political behaviours of individuals who belong to ethnie groups or communities. In 
these instances, ethnic group members or immigrants may participate in politics in order to bring benefit to others. Again, this interpretation doesn't necessarily mean that norms do not impact individual or group behaviour but rather that there may be other additional incentives for participation.

\section{SOCIAL CAPITAL AND TRUST}

Trust is commonly associated with social capital but as a component of social capital, it appears to be somewhat understudied and not understood. Generally, it has been observed that as trust levels increase so does social capital. Here, it is assumed that trust mitigates transaction costs commonly associated with collective action problems (Uslaner 2002). This has led some to conclude that trust is an integral part of solving collective action problems like voting (Putnam 1995; 2000; Uslaner 2002).

Two types of trust emerge from the existing literature: strategic and generalized. Strategic trust tends to characterize trust between certain people in certain contexts whereas generalized trust connotes more of a worldview where trust is extended to all. Typically, it appears that generalized trust is more favourable for increasing participation because although it is believed that strategic trust reduces transaction costs, it cannot explain why individuals would engage in their communities with people they do not necessarily know (Uslaner 2002).

Uslaner (2002) uses his distinction between strategic and moralistic trust to question whether Putnam's (1993) conceptualization of social capital between groups and within groups otherwise known as 'bonding' and 'bridging' social capital, to later be discussed. Instead, Uslaner suggests that it is trust that determines individual's behaviours and not their activity in 
voluntary associations that predicts actions. Accordingly, membership in these associations comes secondary only after individuals have already adopted some level of trust.

Supporting this assertion, Rubenson (2005) questions whether individuals who join social networks, or associations gain greater trust from their membership or if they must already possess higher levels of trust in order to join. Similarly, Rubenson expresses concern that individuals may actually be motivated to participate in collective action because of mistrust. Accordingly, individuals are motivated to participate because they cannot trust others to do what is best. It seems plausible that both high levels of trust and mistrust could facilitate collective action whereas more mediocre levels of trust are associated with indifference. However, such speculation would require further empirical testing.

Trust levels have also been studied in diverse settings. The findings, however, have consistently suggested that lower trust levels are associated with diversity. On the contrary, in their cross-comparative study of Europe, Hooge at al. (2007) found that there is a general trend whereby diverse societies are more trusting but not shown to be statistically significantly. Of particular interest, the most homogenous countries like Poland, Hungary and Belgium were characterized by low levels of trust. Perhaps though, related to Rubenson's (2005) comment on mistrust, one could speculate that both high levels of trust and low levels of trust facilitate collective action.

In their study of social cohesion and diversity, Soroka et al. (2007) found that immigrants are not necessarily less trusting of others. Instead, trust levels tended to be associated with ethnicity. Those of British and Northern European descent were more trusting than those from the Caribbean, Africa, South Asia and the Middle East. Furthermore, members from less trusting 
ethnicities tended to develop greater trust levels when they themselves resided in less diverse neighbourhoods.

\section{SOCIAL CAPITAL AND NETWORKS}

Social networks are an integral part of social capital theory. Portes (1995) defines social networks as ongoing interactions between individuals. These interactions are crucial because, "they embed individuals within a larger framework, a framework that acts as both a source of resources, in the form of information and support, and as a source of pressure, encouraging individuals to adhere to the norms of the community" (Simpson Bueker 2006, 126). Here, we see that networks are directly related to social norms, strengthening normative pressures and constraints.

Social networks are often measured in terms of their composition and density. The composition or membership can, for example, indicate the amount of peer pressure associated with following norms. According to Putnam (1993), of particular importance is whether

members of social networks are like one another. Here, Putnam distinguished between 'bridging' and 'bonding' social capital.

Bridging social capital occurs when individuals interact with others who are different from themselves; commonly differences are in terms of race, gender or class. Conversely, bonding social capital is produced when individuals interact with those who are like themselves. The assumption has been made that bridging social capital creates more favourable conditions for collective action since individuals will be more trusting and more willing to cooperate with others. 
Concerning immigrants, it may be necessary to determine whether they enter social networks with native-born or purely with other immigrants. Existing studies indicate that immigrants joining social networks with a high proportion of native-born will experience increased political incorporation as a result of this networking. Portes and Jensen (1987), for example, suggest that immigrants may feel pressure from their interactions with the native-born community to participate in politics.

The density of social networks is often defined as interactions across multiple contexts. Typically, density is measured through computer programs, like GRADAP, utilized in van Heelsum's study of the Netherlands (2002), which maps and analyzes the linkages between different organizations. Significantly, density is shown to indicate greater social pressures and controls for following norms like the civic duty to vote. Thus, as social networks become denser, the normative pressure to participate in politics increases (Simpson Bueker 2006, 128-130). It is also worth mentioning that social networks tend to be manifested in voluntary associations.

Interestingly, Sidney Tarrow (1996) contends that the "state plays a fundamental role in shaping civic capacity" (395), emphasizing a state-centred approach to social capital. Accordingly, the state essentially facilitates social capital through government, public policies and economic conditions. In his comparative study of Spain and Brazil, Omar Encarnación (2003) argues that social capital is the product of leadership and state institutions. Similarly, scholars Skocpol et al. (2000) contend that social capital cannot exist independently in the realm of civil society because voluntary associations depend on state support.

Of particular interest to how the state conditions social relations and networks in diverse settings is Canada's Multicultural Policy. Considering the role of the state in determining social networks, very little has been written on how state policies of multiculturalism and assimilation 
affect social networks. Perhaps the role of government must be given more attention in scholarly studies to determine how the state and state polices mitigates the effect of diversity on societal networks.

One could speculate, for example, that policies like multiculturalism, which encourage difference, are detrimental to social networks. This is because multiculturalism highlights the unique attributes of cultural groups which could lead to mistrust and a lack of cooperation between people, who the state intentionally promotes as being different. Similarly, approaches of assimilation may be beneficial for networks since they emphasize shared characteristics and a sense of "togetherness".

Conversely, one could also speculate that state policies celebrating differences may actually encourage social interaction and understanding of people not like one's self, ultimately enabling networks across ethnic, racial and religious lines. In this instance, perhaps one's suspicions about others who are different can be dispelled by the state through education. Here, the reverse would be true for policies of assimilation which may breed fear from others who are different. Again, it remains unknown how state policies of multiculturalism and assimilation affect social cohesion.

\section{SOCIAL CAPITAL AND COLLECTIVE ACTION}

Social capital has also been associated with collective action and since voting is a form of collective action, it is particularly important to consider this link. Collective action associated with social capital is not always deemed beneficial to society. For example, voluntary associations can include gangs and groups involved in organized crime. Similarly, Portes (1998) draws attention to the fact that the very nature of associations invokes elements of exclusion. 
Upon further investigation, however, there appears to be a positive link between social capital and political participation.

Stolle (2003) contends that most studies on voluntary associations demonstrate that members of associations and organizations participate more actively in politics than nonmembers. Particularly, Stolle references the work of Hanks and Eckland (1978) and Olsen (1972) who found that group membership increased the likelihood of individuals' propensity to vote. Similarly, members of voluntary associations tend to exhibit more democratic and civil attitudes (Stolle 2003, 24). Here we can see a positive correlation between social capital and political participation. Meanwhile, studies have also shown that the number and type of associations to which people belong is directly related to their political engagement (Wuthnow 1999).

In a related study, Almond and Verba (1963) found that members of voluntary associations were not only more likely to be engaged in political activity such as voting, but that they tended to be more informed about politics and more optimistic about their ability to influence politics and democratic norms. Verba et al.'s book on civic skills (1995) contends that the skills learned through education, the workplace and voluntary associations equip individuals with the necessary means for engaging in political activity. From Almond and Verba's (1963) contributions to the literature, we can see social capital fostering political participation.

Although voluntary associations may be non-political in nature, often the activities in which these groups engage, such as attending a meeting, planning a meeting, writing a letter or making a speech or presentation, foster skills which are directly transferable to political participation (Verba et al. 1995, 312). This is an important point linking social capital and 
political participation. Unfortunately, little appears to be published on immigrant voluntary associations and the transferability of skills to political engagement.

It would be necessary to determine whether immigrant based voluntary associations are more orientated towards encouraging participation in more immediate settlement issues such as finding employment, or whether skills learned are automatically applied to other forms of political engagement such as voting in an election. Such considerations would greatly enrich our understanding of social capital and the political participation of immigrants. Similarly, there is a gap in the literature exploring the social relations between immigrant groups and how this may influence social capital and thus political participation.

Figure 4 provides a summary of how social capital, neighbourhood diversity and voting are all related. As shown neighbourhood diversity, whether ethnic heterogeneity or homogeneity, affects social norms, social networks and trust. In the case of social norms, diversity affects the strength of one's civic duty to vote whereas, diversity also affects social networks which serves as an enforcement mechanism to vote. In both instances, ethnic homogeneity is generally favoured within the existing literature to produce an outcome of participation. Trust is also influenced by diversity since trust in others and trust in others to vote can facilitate or inhibit political behaviours. Here, however, trust formed within diverse communities and across ethnic groups, albeit more difficult to form, can lead to a more conducive type of trust in voting.

In Figure 4, social norms, social networks and trust all facilitate social capital as they help structure the relations between individuals. What remains crucial is that social capital and the collective value of social networks impacts both the willingness to engage in civic endeavours and one's willingness to cooperate collectively. This willingness is then translated into a willingness to solve collective action problems, an example of which is voting. 
Figure 4: Connecting Immigrant Voting to Social Capital and Neighbourhood Diversity

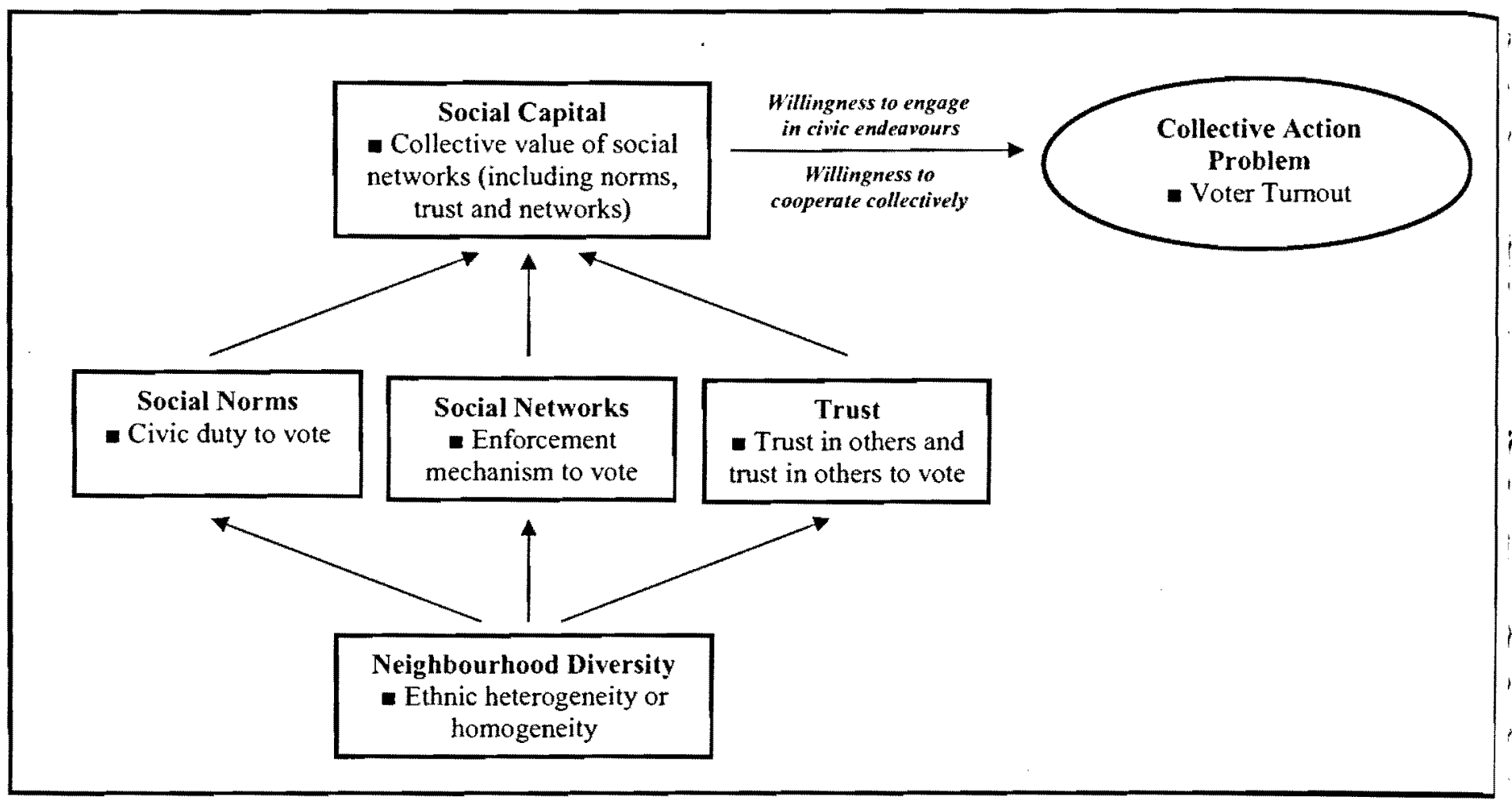

\section{MEASUREMENT, DATA AND METIIODOLOGICAL APPROACHES}

Studies on diversity and political participation vary greatly in terms of their methodology. There are two main approaches for how scholars have analyzed the relationship between diversity and political participation. The first is to utilize survey data to create both bivariate and multivariate models to test the robustness of the relationship between diversity and political participation. For example, Putnam (2007) and Rubenson (2004) both use the nationwide 2000 Social Capital Community Benchmark Survey to create empirical models.

Of importance, this survey was geo-coded allowing both Putnam and Rubenson to determine where respondents live in addition to their individual characteristics like age, gender and education. Other data sets, like the Current Population Survey, utilized by Ramakrishnan (2005) in his research, fail to provide information about individual respondent's neighbourhoods, 
making it impossible to conclude anything about how individual political behaviours are related to neighbourhood level diversity. Instead, conclusions can only be drawn on general participation at the state level. This is an important consideration given that only some studies allow for the prediction of individual's behaviours.

In Alesina and La Ferrara's empirical work $(2000 ; 2002)$, they utilize the General Social Survey in the United States from years 1974 to 1994, which measures a variety of social indicators and demographic characteristics. Alternatively, Bilodeau (2009) relies on data from the Australian Election Studies in 1998, 2001 and 2004 and the 2004 Australian Election Study Special Sample of Immigrants. Here, Bilodeau's sample size of immigrants is relatively small and in order to increase validity, he groups immigrants from non-English speaking countries together as one. This problem with a small sample size highlights one of the common obstacles associated with studying immigrants and ethnic groups.

A second approach, sometimes also utilizing survey data, is a rank-order correlation where ethnic minority groups are essentially ranked according to specific attributes. When these rankings line up, a correlation is suggested between the dependent and independent variable. However, this approach alone cannot determine whether the correlation is significant. In Fennema and Tillie's study of Amsterdam (1999), which has been replicated (see van Heelsum 2002; Jacobs et al. 2004), they ranked ethnic groups according to voter turnout, number of councillors per ethnic group, number of organizations per ethnic group, density of ethnic organization and percentage of isolated organizations.

There are a number of methodological concerns related to the study of diversity and political participation. Interestingly, with the exception of Putnam (2007) and Rubenson (2004), few scholars have brought forth any of these issues within the framework of their own research. 
The first methodological problem is what Putnam identifies as "issues of self sclection" (153). Here, the issue is whether certain people, possessing certain characteristics purposely choose to live in a distinct location. If this were the case, then it remains unclear whether it is diversity which affects their actions. Putnam provides an example of parents choosing to live near a school, noting that living near a school does not cause one to necessarily become a parent. This highlights the problem of causality whereby it is unknown whether individuals choose to live somewhere because of who they are or whether their actions are secondarily affected by diversity.

A second methodological problem is whether diversity affects people differently. In other words, it remains unknown whether some people are more susceptible to the effects of diversity. Many studies, although not all, control for individual variables such as sex, age, income, education and race in order to avoid making false claims. In fact, Putnam (2007) contends that there are no significant differences between individuals or groups, which would lead one to believe that diversity does not affect people differently. However, Putnam cautiously notes that there are subtle differences between different indicators set to measure similar things which affect groups variably. Thus, some caution must be exercised given there is much unknown about the interactional effects of individual variables on how diversity affects individuals.

A third issue concerns definition. Although studies may concisely define things like neighbourhood, diversity or different ethnic groups, these definitions may differ greatly from how actual respondents conceptualize these same concepts. In the instance of neighbourhoods, studies often define such geographic units by census tract whereby a respondent may understand their neighbourhood as three blocks north and three blocks south from their residence and include only those neighbours they have met or seen. This problem has garnered the attention of 
some scholars (Oliver 2001; Putnam 2007) but it appears that little has been done methodologically to reconcile how scholars and residents define communities.

It may also be difficult to compare studies where scholars have defined the concept of community differently. This is particularly true when the size of community varies. Bilodeau (2009) for example, defines community by Australian federal constituency units, which are relatively large whereas Putnam (2007) and Rubenson's (2004) data set allows communities to be defined as much smaller entities. Given what is already known, it is likely that the nature of social capital varies when the size of a community increases.

Similarly, by simplifying diversity and characterizing it by the presence of different ethnic groups, important information may be lost. Particularly, utilizing single categories like 'Hispanic' for sizeable and diverse groups of people may erode larger conceptions of diversity. This is because the grouping 'Hispanic' may already contain a diverse group of people. In the Canadian context, the category of 'South Asian' includes groups of people with different religions, from different countries who themselves would view those within the grouping of 'South Asian' as different or diverse (Ghosh 2007). This methodological problem of social construction has garnered the acknowledgement of most academics; however, it remains difficult to study diversity without the use of ethnic categories.

Fourth, perhaps one of the greatest problems is that all studies tend to be comparative in nature, comparing data from at least two different neighbourhoods; often one that is considerably heterogeneous and one that is more homogenous. This comparison in and of itself is not problematic and leads to results which allow scholars to make conclusions based on multiple locations, increasing their overall validity. The issue, however, is that few studies are longitudinal, indicating that it is unknown how diversity affects communities and people over 
time (Putnam 2007). Consequently, it remains unknown whether under increasingly or stable diverse conditions, individuals eventually become more trustworthy of others or more willing to interact and engage in collective action.

\section{FINDINGS: AN OVERVIEW OF THE EXISTING LITERATURE}

In his study of Australia, Bilodeau (2009) examines whether immigrants living in federal constituencies with higher concentrations of immigrants participate more in politics than other immigrants. Living amongst higher concentrations of immigrants could indicate either greater diversity or homogeneity given that immigrants can be from the same ethnic group or a different ethnic group. In this study, however, Bilodeau is particularly interested in how ethnic segregation, typically meaning homogeneity, affects immigrant political incorporation.

Utilizing a t-test, Bilodeau finds evidence suggesting that political engagement tends to increase amongst immigrants living in areas with a high proportion of immigrants. This relationship is particularly salient when considering the variable 'discussing voting intention' whereby as the percentage of immigrants residing in a constituency increases so does the propensity to discuss voting. In areas with $0-15 \%$ immigrants, $39 \%$ discuss their vote intention, whereas this rises significantly to $43 \%$ and $54 \%$, respectively, in areas with $15-30 \%$ immigrants and $30 \%$ and above. This is comparable to only $33 \%$ of the general Australian population discussing their intention to vote (140).

In this test, it is unknown whether Bilodeau is testing the effect of diversity or homogeneity. This is because there is no way to establish whether high proportions of immigrants denote immigrants from different ethnic groups or whether immigrants are from the 
same ethnic group. Therefore, although this finding may have greater implications for immigrant voting and political incorporation, it fails to address the effects of diversity on immigrant voting.

Rectifying this issue, Bilodeau examines whether the concentration of immigrants from one's own ethnic group affects immigrant political participation. In this instance, Bilodeau is isolating the effect of homogeneity. Here, immigrants are given a score between 0 and 3 representing the number of political activities they are engaged in. The effect of ethnic concentration is significant for South East Asian, Southern European and South Eastern European immigrants whereby their participation increases, as does the percentage of people like themselves within their community.

This increase is seen as residential concentration rises from $4 \%$ to $8 \%$, indicating a very small concentration which in some instances arguably is better characterized as diversity. The same relationship does not hold for immigrants from English speaking countries of origin. Similarly, the native-born Australian population are not affected, suggesting that only some immigrant groups are disproportionately affected by diversity.

Interestingly, Mesch (2002) employs a similar methodology when studying the effect of residential concentration on immigrant participation in local elections in Haifa, Israel. In this study, Mesch is particularly interested in how the concentration of Russian immigrants affects first whether Russian immigrants participate in politics and second whether they are more likely to support an ethnic party marked by a Russian candidate. Mesch measures ethnic concentration by intervals of $0-10 \%, 11-40 \%$ and $41-60 \%$ representing the percentage of Russian immigrants in a neighbourhood. These percentages are much higher than those found in Bilodeau's (2009) study given that immigrant residential concentration in Haifa tends to be much greater. 
Mesch finds that the concentration of immigrants living within neighbourhood is correlated with both voting and voting for an ethnic party. Here, the more Russians residing in a given neighbourhood, the more likely Russian immigrants are to vote and vote for a Russian candidate. Commenting on this finding, Mesch notes, "immigrants who live in areas with high concentrations of co-ethnics are embedded in a web of social relationships with family, friends, neighbours and co-workers" (160-161). Thus, Mesch emphasizes what social capital theorists have always advocated: that networks impact political engagement.

Bilodeau (2009) provides three possible explanations for his findings which help to explain theoretically why homogeneity creates favourable conditions for immigrant political participation. First, Bilodeau suggests that social connectedness is well developed within ethnic communities. Accordingly, social networks in ethnic enclaves tend to be strong. Relating back to the literature on social networks and collective action problems, one can understand how it would be easy to assume that political participation would increase in less ethnically diverse settings. Here, ethnic enclaves do not represent diversity despite their overall contribution of diversity to greater society since the neighbourhood population tends to be homogenous, consisting of only one ethnic group.

Nonetheless, one of the problems with this assumption is whether voting is actually a social norm within the ethnic community. This can relate back to White et al.'s (2008) work on immigrant political socialization which was inconclusive as to how immigrants are politically socialized. Again, it must be acknowledged that some immigrants come from countries where voting may not be the norm. It would be particularly interesting to compare participation rates of immigrants originating from countries with enforced compulsory voting and those without to determine whether voting norms are persistent in both contexts while in Canada. 
Second, Bilodeau (2009) suggests that political parties may have greater incentive to mobilize more densely populated ethnic communities given the associated payoff. Rosenstone and Hansen's work on political competition (1993) shows that canvassing tends to result in increased voter turnout. As earlier studies have suggested, political exposure leads to immigrants being more receptive to participating. Furthermore, Ramakrishnan (2005) notes that the concentration of ethnic groups lowers the per capita cost of ethnic mobilization by political parties, overall incentivising canvassing (99).

Mobilization and recruitment are also central to Uhlaner's (1989) relational goods argument. Accordingly, people pursue 'relational goods' in making decisions about their actions. Relational goods are goods acquired only in the presence of other people and include things like solidarity, friendship and acceptance from others. Relational goods account for why individuals join voluntary associations and help explain why solidarity forms between individual members.

Concerning voting, Uhlaner contends that turnout should be highest for groups who unanimously prefer one candidate over another and mobilization is especially important in attaching political salience to group identity. This is especially true when groups are geographically concentrated. Uhlaner supplies the example of French Canadians and Asian Americans where French Canadians participate more in politics because they are a politically salient group with interests to defend (278-280). Asian Americans, however, have not yet defined themselves as a politically salient group.

Leighley (2001) makes the counter-point that in the United States, Blacks feel that political parties have failed to adequately mobilize their support since it is perceived to be a waste of time because it is assumed that Blacks will overwhelmingly support the Democrats. In the 2009 Presidential Election, however, Blacks were mobilized but it remains unknown whether 
this would have been the case had the party candidate not been Barack Obama. In the Canadian context, however, elections are relatively less polarized given the multi-party system and despite immigrants tending to overwhelmingly vote Liberal in the past (see Blais 2005), more recent trends, such as Conservative inroads in the Greater Toronto Area, suggest that all viable political parties are competing and mobilizing the immigrant vote.

Finally, Bilodeau (2009) references the argument and title of Jan E. Leighley (2001) book "Not Just Numbers". Here, based on earlier research by Dawson (1994), both Bilodeau (2009) and Leighley (2001) make the argument that members of larger racial or ethnic communities may be motivated to participate in politics as an instrumental component to being part of the community (25-26). In other words, members do not participate based on individual member's rationality but as part of a collective effort, evoking the phrase 'strength in numbers'.

Putnam's study (2007) also follows a very specific logic when determining the effect of diversity on political participation. Central to Putnam's argument is the assumption that there is a strong relationship between trust and diversity, whereby people living in more diverse communities tend to trust their neighbours less than those living in less diverse settings. Again, as previously shown, trust is correlated with social capital which is directly related to political participation.

In his study, Putnam is particularly interested in how diversity affects both in-group and out-group trust, meaning trust between those who are ethnically or racially different and trust between members of the same ethnic or racial group. Concerning out-group trust, Putnam's findings reinforce earlier studies by Alesina and La Ferrara (2000; 2002), Costa and Khan (2003) and Anderson and Paskeviciute (2006) all of which found that diversity leads to decreased levels of trust. In general, people become less trusting of others when 'others' become increasingly 
unlike themselves. The implication of this is that individuals living in diverse communities will be less likely to engage in collective action problems and consequently will be less likely to participate in politics.

Interestingly, Putnam finds that not only is out-group trust relatively lower in diverse settings, but that in-group trust is also low. This suggests that diversity negatively affects trust levels between all members of a community, irrespective of whether members share common characteristics. Accordingly, as a community becomes increasingly diverse all members will become less trusting of each other. So what are the implications of Putnam's study on immigrant political participation?

Unfortunately, Putnam does not isolate immigrants as a group meaning that it is impossible to draw definitive conclusions. Instead one can speculate that as members of communities, immigrants likely become less trusting of their own ethnic group as diversity increases. Consequently, ethnic communities may provide conditions most favourable to engaging in politics, but as outside diversity increases, the role of the ethnic enclave may be diminished since in-group trust will likely be lessened. This tells us very little about whether immigrants are disproportionately affected by diversity but Putnam's study does suggest that individuals become less trusting of their own ethnic and racial groups in diverse settings.

An attempt has also made by Alesina and La Ferrara (2000) to test a series of models based on previously held assumptions about racial and ethnic diversity and social capital. These assumptions originated from data revealing countries like Canada and Scandinavian have both high levels of social capital and high levels of ethno- racial homogeneity (848). Although they proceeded to empirically test this assumption, the basic principles may be false. It may be true that Scandinavian communities are relatively homogeneous but Canada is well regarded for its 
diversity, calling into question Alesina and La Ferrara's basic assumption that diversity and social capital are negatively correlated.

Yet despite this shortcoming, Alesina and La Ferrara (2000) find that participation is lowest in more ethnically fragmented communities. Here, individuals generally show preference for interacting with others who are most similar to themselves in terms of income, race and to a lesser degree, ethnicity. Not surprisingly, those least likely to participate in any group activities are those with the strongest views against racial mixing. Similarly, racial fragmentation had the strongest negative effect on participation suggesting that racial diversity may be the single most important variable in looking at community diversity and political participation.

In a later study, Alesina and La Ferrara (2002) found additional evidence reinforcing their earlier findings on trust and diversity. Utilizing data from the General Social Survey from 1974 to 1994, they found that racially fragmented communities have lower trust levels than more homogenous communities. In this study, the Racial Fragmentation Index was utilized representing the probability that two randomly drawn individuals in a given geographic area will belong to the same race.

The Index computes a value between 0 and 1 , with 1 indicating that two randomly drawn individuals will be from the same race, thus indicating complete homogeneity. Alesina and La Ferrara (2002) found that communities ranking 0.06 on the Racial Fragmentation Index were nearly twelve percent less trusting than more homogenous communities with the value 0.61 (222). This finding reinforces similar findings within social capital theory where individuals are most likely to trust others who are most like themselves (Dasgupta 1988; Uslaner 2002). Additionally, their data reveals that minorities in general are overall less trusting than others but Whites were significantly less trusting than any other group when residing in a diverse 
neighbourhood. Although not directly addressing immigrants, Alesina and La Ferrara's finding may have implications for immigrants who generally include members of minority groups. Although not empirically tested, it is plausible that immigrants are overall less trusting but that in diverse settings non-immigrants are even less trusting.

Diverging from the linkage between social capital and political participation, Diana Mutz's empirical work on political participation (2002) also deserves brief mention even though she does not directly test the effects of diversity on voting. Instead, Mutz contends that crosspressures, the manifestation of a wide range of varying political opinions, leads to political ambiguity. Subsequently, this causes individuals to become overwhelmed and unable or unwilling to engage in political action. For example, despite feeling a sense of loyalty to one's chosen candidate or political party, after being exposed to opposing viewpoints an individual may feel that they are being pulled in two directions, having loyalty to one candidate and agreeing with another opposing candidate or political party.

Mutz makes a compelling argument that cross-pressures hinder political engagement but just how can this be related to ethnic diversity and immigrant political participation? Although not empirically proven, it is likely that there is a wide range of political opinions in diverse settings. Particularly, this is likely in situations where there are conflicts over resources. Consequently, it would be of value to expand Mutz's analysis to diverse and homogenous settings to see if her findings translate and impact immigrants.

In addition to this research originating from the United States, studies have been conducted elsewhere to determine the relationship between neighbourhood diversity and political participation. For example, Fennema and Tillie's (1999) study on Amsterdam suggests a causal link between social capital and political participation, where membership in voluntary 
associations is correlated with voting. More specifically, Fennema and Tillie conclude that political participation and trust is a product of civic engagement (721).

This study, however, was conducted through what is termed a 'rank correlation' where ethnic minority groups were essentially ranked according to specific attributes. These rankings line up, indicating that there is positive correlation between the dependent and independent variable, which could imply that there is a significant relationship. The main minority or ethnic groups in the Netherlands are Turks, Moroccans, Surinamese and those from the Antilles.

Based on this publication, van Heelsum (2002) tests whether these findings are generalizable to the whole of the Netherlands. Using a similar rank ordering of five variables, van Heelsum concludes that the stronger the civic community, the more likely minorities will participate in politics. These variables are: (1) voter turnout; (2) number of councillors per ethnic group; (3) number of organizations per ethnic group; (4) density of ethnic organization and lastly (5) percentage of isolated organizations.

In all cases, Turks rank first, followed by Moroccans and then Surinamese leading to the conclusion that civic engagement is related to political participation. Although the finding is consistent with Fennema and Tillie's (1999) work on Amsterdam, the use of rank ordering may only suggest a relationship rather than confirm significance. This is because it is impossible to determine actual significance given that this methodology does not allow for the precise measurement of correlation. It is unknown why these findings were not formalized using a correlation matrix or regression.

Despite obvious empirical shortcomings, Fennema and Tillie's (1999) study was again replicated, this time in Brussels. Of particular interest, the minority groups studied in both sets of research are Turks and Moroccans. In this study, Jacobs et al. (2004) find that although Turks 
score higher than Moroccans on indicators of ethnic civic community, their political participation remains lower than Moroccans. Significantly, this finding suggest that the relationship between social capital, and more specifically, ethnic civic communities and networks is not entirely clear since what has been proved true in Amsterdam (Fennema and Tillie 1999) and the Netherlands on the whole (van Heelsum 2002) cannot be directly applied to the case of minority groups in Brussels.

Moving away again from rank order correlations, in a study on Denmark, Togeby (1999) found that immigrants residing in concentrated areas were moderately more likely to participate in local politics than those residing in less concentrated areas. Togeby specifically looked at voter turnout of Turks and Lebanese in 1997 local elections across Denmark and employed a multivariate analysis accounting for many factors, including length of residence. This study emphasizes the role of collective mobilization in promoting political engagement and concludes that the political mobilization of ethnic groups in Denmark helps explain why immigrants have relatively high voter turnout levels.

Eric Oliver's study (2001) of suburban life in America touches upon how diversity, or lack therefore, affects the political participation of different ethnic groups. Utilizing data from the 1990 Citizen Participation Survey from 1989 and 1990 as well as the American National Election Study from 1996, Oliver constructs a series of contextual models. Through multivariate regression analysis, Oliver discovers that the relationship between racial segregation and political engagement is indeed complex.

Overall, Oliver suggests that residents of predominantly White communities are less likely to participate in politics, as well as other related civic endeavours, than individuals living in more diverse communities. This finding is of course contradictory to the overwhelming 
majority of existing studies which portray diversity as having a negative influence on political activities like voting. Oliver cautiously notes, however, that diverse communities tend to also be characterized by other attributes which may also play a role in this relationship. For example, racially diverse cities tend to be politicized, more densely populated and face a disproportionate number of social problems like poverty and crime.

In contrast to Bilodeau's (2009) theoretical assertions for why diversity hinders political engagement, Rubenson (2004) suggests the possibility that diversity ought to increase political participation due to a conflict over resources. Accordingly, those living within diverse communities have more incentive to participate in politics in order to secure resources for their own group and limit their disadvantage. Thus, individuals living in diverse communities view ethno- racial relations in terms of a zero-sum competition.

This assertion is further tested in Rubenson's multilevel model which reveals that diversity affects groups differently. For example, Asian and Blacks living in diverse communities are more likely to engage in politics than members of their same racial groups living in more homogenous settings. The same, however, is not true for Hispanics where the effect of diversity appears insignificant. Meanwhile, Whites become increasingly less likely to vote as diversity increases within their communities.

Rubenson's findings reveal the complexity of determining the impact of community diversity on political participation. This study does not analyse immigrants per se but given the history of immigrant flows, it is likely that the racial grouping of Asian and Hispanics includes a high proportion of immigrants. Despite this, it is impossible to draw definitive conclusions from this study as to whether diversity affects immigrant political participation disproportionately. 
Looking through the existing Canadian scholarship there appears to be a very limited amount of studies on how diversity in Canada affects trust, networking, norms or collective action problems. One of the few Canadian-based studies isolated federal ridings according to their overall concentration of immigrants and compared these levels of diversity to voter turnout (Jedwab 2006).

The data reveals that ridings with higher concentrations of immigrants had lower than average rates of voter turnout during the 2004 and 2006 federal elections (see Table 3). The differences between turnout rates in diverse ridings and overall turnout appear moderate and further studies would be required to determine the overall significance. It would also be necessary to compare this data with ridings that have the least foreign-born. Yet, because this data remains aggregated, it is impossible to draw conclusions on how diversity affects individual political behaviours. 
Table 3: Voter Turnout in the 2004 and 2006 Federal Elections and The Percentage of Immigrants in Each Riding, Ontario.

\begin{tabular}{|l|l|l|l|}
\hline Location & $\begin{array}{l}\text { \%of riding } \\
\text { population } \\
\text { born outside } \\
\text { Canada }\end{array}$ & $\begin{array}{l}\text { Turnout in } \\
\mathbf{2 0 0 4} \text { Election }\end{array}$ & $\begin{array}{l}\text { Turnout in } \\
\mathbf{2 0 0 6} \\
\text { Election }\end{array}$ \\
\hline Canada-Overall & 66.7 & 60.9 & 64.7 \\
\hline Scarborough-Rouge River & 51.1 & 57.0 \\
\hline Scarborough-Agincourt & 64.0 & 56.4 & 61.7 \\
\hline York West & 61.2 & 48.5 & 57.9 \\
\hline Markham-Unionville & 60.0 & 56.1 & 61.7 \\
\hline Don Valley East & 59.6 & 59.4 & 63.8 \\
\hline Mississauga East-Cooksville & 58.0 & 52.4 & 58.3 \\
\hline Vancouver South & 57.7 & 55.8 & 56.4 \\
\hline Richmond & 57.2 & 56.7 & 56.3 \\
\hline York Centre & 57.0 & 56.8 & 61.1 \\
\hline Etobicoke North & 55.8 & 51.0 & 59.0 \\
\hline Davenport & 55.5 & 52.9 & 60.6 \\
\hline Vancouver Kingsway & 55.0 & 58.0 & 58.7 \\
\hline Mississauga-Brampton South & 53.6 & 53.8 & 60.0 \\
\hline York South-Weston & 53.5 & 51.7 & 60.0 \\
\hline Saint-Laurent-Cartierville & 46.9 & 54.3 & 55.3 \\
\hline Burnaby-New Westminster & 46.0 & 59.0 & 60.1 \\
\hline
\end{tabular}

Source: Jedwab $(2006,5)$

\section{CONCLUSIONS}

This literature review highlighted the various political models to better explain political behaviour, demonstrating that there is a gap and subsequent need to understand how context at the community level affects individual political behaviours. This is especially true given the changing nature of context which is currently characterized by the influx of immigrants representing a diverse range of ethnic identities. This has led to this review's quandary: Does community diversity affect individual political behaviours? If so, then are immigrants disproportionately affected by diversity? 
To summarize, it appears that community diversity does affect political participation to some degree but this is not without qualification. First, although this review explored the existing literature, overall, there is a scarcity of empirical work to substantiate any claims. Considering the amount of scholarly work on other more traditional political models, efforts must be diverted towards studying context. This is especially true given evidence that older models fail to capture community level variables.

Second, the direction of the relationship between diversity and political participation is somewhat unclear. In some instances diversity has a positive impact while in others the impact is negative, leading to questions concerning directionality. In fact, the theoretical arguments for and against diversity by Bilodeau (2009) and Rubenson (2004) are so convincing that it is completely plausible that both extremes of diversity and homogeneity could positively impact political participation.

Similarly, as studies have shown, the direction of the relationship between diversity and political participation is not necessarily the same for all. Evidence suggests that members of some groups are affected differently than others. For example, it appears that diversity is a better predictor of Black and Asian political participation than Hispanic.

Without being able to adequately answer the question of how diversity affects political engagement, it is also not possible to conclude whether immigrants are disproportionately affected by diversity. Again with this second question, there is also a lack of existing empirical evidence. In fact, there appears to be even less published on immigrant political participation despite the obvious connection between increasing diversity and immigrant flows.

This review also posed a third question as to whether social capital, as a theory, could help explain how context affects political behaviours within diverse setting. Here, the existing 
literature revealed more conclusive and even optimistic results. It appears likely that social capital can provide some indication of individual's political behaviours given existing evidence that diversity affects the structure of societal relations which can subsequently impact whether an individual participates in politics. Consequently, this review highlights the salience of social capital as a means for better understanding political participation both within homogenous and heterogeneous communities. 


\section{BIBLIOGRAPHY}

Aldrich, H. John. 1993. "Rational Choice and Turnout". American Journal of Political Science 37(1): 246-278.

Alesina, Alberto and Eliana La Ferrara. 2000. "Participation in Heterogeneous Communities". The Quarterly Journal of Economics 115(3): 847-904.

Alesina, Alberto and Eliana La Ferrara. 2002. "Who Trusts Others?" Journal of Public Economics 85(2): 207- 234.

Almond, A. Gabriel. 1960. "A Functional Approach to Comparative Politics". In The Politics of Developing Areas. Almond, Gabriel and James Coleman (eds.). Princeton: Princeton University Press. pp. 26- 33.

Almond, A. Gabriel and Sidney Verba. 1963. The Civic Culture: Political Attitudes and Democracy in Five Nations. NJ: Princeton University Press.

Anderson, G. Christopher and Jerome H. Black. 2008. "The Political Integration of Newcomers, Minorities and Canadian-Born: Perspectives on Naturalization, Participation and Representation". In Immigration and Integration in Canada in the Twenty-First Century. Biles, John, Meyer Burstein and James Frideres (eds.). Kingston: Queens' University School of Policy Studies. pp. 45- 76.

Anderson, J. Christopher and Aida Paskeviciute. 2006. "How Ethnic and Linguistic Heterogeneity Influence the Prospects for Civil Society: A Comparative Study of Citizenship Behavior". Journal of Politics 68(4): 783-802.

Axelrod, M. Robert. 1986. "An Evolutionary Approach to Norms". American Political Science Review 80(4): 1095-111.

Balakrishnan, T.R and Stephen Gyimah. 2007. "Spatial Residential Patterns of Selected Ethnic Groups: Significance and Policy Implications". In The Changing Face of Canada.

Roderic P. Beaujot and Don Kerr (eds.). Toronto: Canadian Scholar's Press. pp. 311 - 328.

Baron, Stephen, John Field and Tom Schuller (eds.). 2000. Social Capital - Critical Perspectives. Oxford: Oxford University Press.

Biles, John, Meyer Burstein, and James Frideres (eds). 2008. Immigration and Integration in Canada in the Twenty-First Century. Kingston: Queens' University School of Policy Studies.

Bilodeau, Antoine. 2009. "Residential Segregation and the Electoral Participation of Immigrants in Australia". International Migration Review 43(1): 134- 159. 
Bilodeau, Antoine. 2008. "Immigrants' Voice through Protest Politics in Canada and Australia: Assessing the Impact of Pre- Migration Political Repression." Journal of Ethnic and Migration Studies 34(6): 975- 1002.

Bilodeau, Antoine and Mebs Kanji. 2006. "Political Engagement Amoung Immigrants in Four Anglo-Democracies". Electoral Insight: Electoral Participation of Ethnocultural Communities 8(2): 43-49.

Black, H. Jerome. 1982, "Immigrant Political Adaptation in Canada: Some Tentative Findings". Canadian Journal of Political Science 15(1): 3-27.

Black, H. Jerome. 1987. "The Practice of Politics in Two Settings: Political Transferability Among Recent Immigrants to Canada". Canadian Journal of Political Science 20(4): 731-753.

Black, H. Jerome and Christian Leithner. 1988. "Immigrants and Political Movement in Canada: The Role of the Ethnic Media". Canadian Ethnic Studies 20(1): 1-20.

Black, H. Jerome. 1991. "Ethnic Minorities and Mass Politics in Canada: Some Observations in the Toronto Setting". International Journal of Canadian Studies 3(Spring): 129-151.

Black, H. Jerome and David Hagen. 1993. "Quebec Immigration Politics and Policy: Historical and Contemporary Perspectives". In Quebec State and Society. Alain G. Gagnon (ed.). $2^{\text {nd }}$ Edition. Toronto: Nelson. Chapter 16.

Blais, André and Robert Young. 1999. "Why Do People Vote?: An Experiment in Rationality." Public Choice 99(April): 39-55

Blais, André. 2000. To Vote Or Not To Vote? The Merits and Limits of Rational Choice. Pittsburgh: University of Pittsburgh Press.

Blais, André. 2005. "Accounting for the Electoral Success of the Liberal Party in Canada". Canadian Journal of Political Science 38(4): 821-40.

Bauder, Harald and Bob Sharpe. 2002. "Visible Minorities in Canada's Gateway Cities". Canadian Geographer 46(3): 204-222.

Burt, Sandra. 2002. "The Concept of Political Participation." In Citizen Politics: Research and Theory in Canada Political Behaviour. Everitt, Joanna and Brenda O'Neill (eds.). Oxford University Press. pp. 232-246.

Bourdieu, Pierre. 1986. "The Forms of Capital". In Social Capital - Critical Perspectives. Baron, Stephen, John Field and Tom Schuller (eds.). 2000. Oxford: Oxford University Press.

Breton, Raymond. 2005. Ethnic Relations in Canada. Reitz, Jeffrey (ed.). Kingston: McGillQueen's University Press. 
Campbell, E. David. 2006. Why We Vote: How Schools and Communities Shape Civic Life. Princeton: Princeton University Press.

Cho, Tam Wendy. 1999. "Naturalization, Socialization, Participation: Immigrants and (Non)Voting". The Journal of Politics 61(4): 1140- 1155.

Chui, W.L. Tina, James Curtis and Ronald D. Lambert. 1991. "Immigrant Background and Political Participation: Examining Generational Patterns". Canadian Journal of Sociology 16(4): 375-397.

Coleman, S. James. 1988. "Social Capital in the Creation of Human Capital". American Journal of Sociology 94(supplement):S95- S12.

Coleman, S. James. 1990. Foundations of Social Theory. Cambridge MA: Harvard University Press.

Costa, L. Dora and Matthew E. Kahn. 2003. "Civic Engagement and Community Heterogeneity: An Economist's Perspective". Perspectives on Politics 1(1): 103-11.

Cialdini, B. Robert and Melanie R, Trost. 1985. "Chapter 21: Social Influence: Social Norms, Conformity and Compliance". In The Handbook of Social Psychology. Gilbert, Daniel T, Susta T. Fiske and Gardner Lindzey (eds.). Volume 2, Edition 4.

Dasgupta, Partha. 1988. "Trust as a Commodity". In Trust: Making and Breaking Cooperative Relations. Gambetta, Diego. (ed.). New York: Basil Blackwell, pp. $49-72$.

Dawson, C. Michael. 1994. Behind the Mule: Race and Class in African-American Politics. New Jersey: Princeton University Press.

Doucet, J. Michael. 1999. "Toronto in Transition: Demographic Change in the Late Twentieth Century". CERIS Working Paper No. 6. Available at: <http://ceris.metropolis.net/ Virtual\%20Library/WKPP\%20List/WKPP1999/CWP06_Doucet_final.pdf

Elster, Jon. 1989. "Social Norms and Economic Theory". Journal of Economic Perspective 3(4): 99- 117.

Encarnación, Omar. 2003. The Myth of Civil Society: Social Capital and Democratic Consolidation in Spain and Brazil. New York: Palgrave Macmillan.

Faist, Thomas. 2009. "Diversity- A New Mode of Incorporation?" Ethnic and Racial Studies 32(1): 171- 190 .

Fehr, Ernst and Urs Fischbacher. 2004. "Third Party Punishment and Social Norms". Zurich IEER Working Paper No. 106. Available at SSRN: <http://ssrn.com/abstract $=495443$ or DOI: $10.2139 / \mathrm{ssm} .495443>$ 
Fennema, Meindert and Jean Tillie. 1999. "Political Participation and Political Trust in Amsterdam: Civic Communities and Ethnic Networks". Journal of Ethnic and Migration Studies 25(4): 703- 726.

Fong, Eric. 1996. "A Comparative Perspective on Racial Segregation: American ande Canadian Experiences". The Sociological Quarterly 37(2): 199- 226.

Fowler, H. James. 2006. "Altruism and Turnout". The Journal of Politics 68(3): 674- 683.

Fowler, H. James and Cindy D. Kam. 2007. "Beyond the Self: Social Identity, Altruism and Political Participation". The Journal of Politics 69(3): 813-827.

Gastwirth, L. Joseph. 1972. "The Estimation of the Lorenz Curve and Gini Index". The Review of Economics and Statistics 54(3): 306- 316.

Ghosh, Sutama. 2007. "Transnational Ties and Intra-Immigrant Group Settlement Experiences: A Case Study of Indian Bengalis and Bangladeshis in Toronto". Geojournal 68(February): 223-242.

Gidengil, Elisabeth, André Blais, Neil Nevitte and Richard Nadeau. 2004. Citizens. Vancouver: UBC Press.

Ginieniewicz, Jorge. 2007. "The Scope of Political Participation". Journal of International Migration and Integration 8(3): 327-345.

Green, P. Donald and Ian Shapiro. 1994. Pathologies of Rational Choice Theory: A Critique of Applications in Political Science. New Haven: Yale University Press.

Hanks, Michael and Bruce K. Eckland. 1978. "Adult Voluntary Associations and Adolescent Socialization". Sociological Quarterly 19(3): 481- 490.

Harles, C. John. 1997. "Integration Before Assimilation: Immigration, Multiculturalism and the Canadian Polity". Canadian Journal of Political Science 30(4): 711 - 736.

Hill, Q. Kim and Jan E. Leighley. 1999. "Racial Diversity, Voter Turnout, and Mobilizing Institutions in the United States". American Politics Quarterly 27(3): 275-295.

Hooghe, Marc, Tim Reeskens and Dietlind Stolle. 2007. "Diversity, Multiculturalism and Social Cohesion: Trust and Ethnocentrism in European Societies". In Belonging? Diversity, Recognition and Shared Citizenship in Canada. $3^{\text {rd }}$ Edition. Banting Keith, Thomas Courchene, and Leslie Seidle (eds.). Montreal, Quebec, Canada: Institute for Research on Public Policy. pp. 387-410.

Hyman, Herbert. 1969. Political Socialization: A Study in the Psychology of Political Behaviour. New York: The Free Press. 
Jacobs, Dirk and Jean Tillie. 2004. "Introduction: Social Capital and Political Integration of Migrants". Journal of Ethnic and Migration Studies 30(3): 419- 427.

Jacobs, Dirk, Karen Phalet and Marc Swyngedouw. 2004. "Associational Membership and Political Involvement Among Ethnic Minority Groups in Brussels". Journal of Ethnic and Migration Studies 30(3): 543- 559.

Jedwab, Jack. 2006. "The 'Roots' of Immigrant and Ethnic Voter Participation in Canada". Electoral Insight: Electoral Participation of Ethnocultural Communities 8(2): 3-9.

Knack, Stephen. 1992. "Civic Norms, Social Sanctions and Voter Turnout". Rationality and Society 4(2): 133- 156.

Langton, Kenneth. 1969. Political Socialization. New York: Oxford University Press.

Lapp, Meindert. 1999. "Ethnic Group Leaders and the Mobilization of Voter Turnout: Evidence from Five Montreal Communities". Canadian Ethnic Studies 31(2): 17-42.

Lefebvre, Pierre. 2004. "Quebec's Innovative Early Childhood Education and Care Policy and Its Weaknesses". Policy Options IRPP. 52-57. Available at: <http://www.irpp.org/ po/archive/mar04/lefebvre.pdfs

Leighley, E. Jan. 2001. Strength in Numbers? The Political Mobilization of Ethnic Minorities. Princeton: Princeton Press.

Mesch, G. Gustavo. 2002. "Residential Concentration and Participation in Local Politics: The Case of Immigrants of the FSU in Israel". Journal of International Migration and Integration. 3(2): 157-177.

Milbrath, W. Lester. 1971. "Individuals and Government". In Politics in the American State: A Comparative Analysis. Jacob, Herbert and Kenneth N. Vines (eds.). Boston: Little Brown.

Mutz, Diane. 2002. "The Consequences of Cross- Cutting Networks for Political Participation". American Journal of Political Science 46(4): 838- 855.

Nevitte, Neil, André Blais, Elisabeth Gidengil and Richard Nadeau. 2000. "Socio-Economic Status and Non-Voting: A Cross-National Comparative Analysis". Prepared for presentation at the XVIII World Congress of the International Political Science Association 1-5 August 2000, Québec.

Oliver, J. Eric. 2001. Democracy in Suburbia. Princeton: Princeton University Press.

Olson, E. Marvin. 1972. "Social Participation and Voting Turnout: A Multivariate Analysis". American Sociological Review 37(3): 317- 333 
Oppenhuis, Erik. 1995. Voting Behavior in Europe: A Comparative Analysis of Electoral. Participation and Party Choice. Amsterdam: Het Spinhuis.

Portes, Alejandro and Leif Jensen. 1987. "Limits of Ethnic Solidarity in the Enclave Economy". American Sociological Review 52(6): 745- 767.

Portes, Alejandro (ed.). 1995. The Economic Sociology of Immigration. New York: Russell Sage Foundation.

Portes, Alejandro. 1998 "Social Capital: Its Origins and Applications". Modern Sociology Annual Review of Sociology 24(August):1-24.

Putnam, D. Robert. 1993. Making Democracy Work: Civic Transitions in Modern Italy. Princeton NJ: Princeton University Press.

Putnam, D. Robert. 1995. "Tuning In, Tuning Out: The Strange Disappearance of Social Capital in America". Political Science and Politics 28(4): 1-20.

Putnam, D. Robert. 2000. Bowling Alone: The Collapse and Revival of American Community. New York: Simon \& Shuster.

Putnam, D. Robert. 2007. "E Pluribus Unum: Diversity and Community in the Twenty-first Century". Scandinavian Political Studies 30(2): 137-174.

Qadeer, A. Mohammad. 2003. "Ethnic Segregation in a Multicultural City: The Case of Toronto, Canada". Ceris Working Paper No. 28.

Ramakrishnan, A. Karthick. 2005. Democracy in Immigrant America: Changing Demographics and Political Participation. Stanford: Stanford University Press.

Reitz, G. Jeffrey. 1980. The Survival of Ethnic Groups. Toronto: McGraw-Hill Ryerson Ltd.

Richmond, H. Anthony and John Goldlust. 1977. Family and Social Integration of Immigrants in Toronto. Toronto: Ethnic Research Programme, York University.

Riker, William and Peter C, Ordershook. 1968. "A Theory of the Calculus of Voting". American Political Science Review 62(1): 25- 42.

Rosenstone, Steven and John Mark Hansen. 1993. Mobilization, Participation and Democracy in America. New York: Macmillian Press

Rubenson, Daniel. 2004. "Community Heterogeneity and Political Participation in American Cities". Prepared for presentation to the 2004 Canadian Political Science Association meeting, Winnipeg 3-5 June 2004. 
Rubenson, Daniel, André Blais, Patrick Fournier, Elisabeth Gidengil and Neil Nevitte. 2004. "Accounting for the Age Gap In Turnout." Acta Politica 39(4): 407.

Rubenson, Daniel. 2005. "Can Social Capital Accounts for Differences in Political Participation Across American Cities." Prepared for 2005 Annual Meeting of the American Political Science Association, Washington DC. 1-4 September 2005.

Saloojee, Anver. 2002. Inclusion and Exclusion: A Framework for Analysis for Understanding Political Participation by Members of Racialized Newcomer Communities. Metropolis Brining Worlds Together Seminar Proceedings. Available: <http:/canada.metropolis.net /events/Political\%20Participation/papers\%20and\%20reports/saloojee_inclusion_e.doc $>$

Siemiatycki, Myer. 2006. "Diversity Our Strength: The Toronto Experience." Transition (Summer): 11-15.

Simpson Bueker, Catherine. 2006. From Immigrant to Naturalized Citizen: Political Incorporation in the United States. New York: LFB Scholarly Publishing LLC.

Skocpol, Theda, Marshall, Ganz and Ziad Munson. 2000. "A Nation of Organizations: The Institutional Origins of Civic Volunteerism in the United States". American Political Science Review 94(3): 527- 546.

Smith, P. James and Barry, Edmonston (eds.). 1997. The New Americans: Economic, Demographic and Fiscal Effects of Immigration. Washington, DC: National Academy Press.

Soroka, S. Stuart, Richard Johnston and Keith Banting. 2007. "Ties that Bind? Social Cohesion in Canada". In Belonging? Diversity and Social Integration in Canada. Banting, Keith, Thomas Courchene and Leslie Seidle (eds.). Montreal: Institute for Research on Public Policy. pp. 561-600.

Stasiulis, Daiva. 1997. "Participation by Immigrants, Ethnocultural/ Visible Minorities in the Canadian Political Process". Paper presented at the Second National Metropolis Conference. Montreal, QC. Available: <http://canada.metropolis.net /events/civic/dstasiulis_e.html>

Stolle, Dietlind. 2003. "The Sources of Social Capital". In Generating Social Capital: Civil Society and Institutions in Comparative Perspective. Hooghe, Mark. and Dietlind Stolle (eds.) New York: Palgrave Macmillian. pp. 19- 42.

Tarrow, Sidney. 1996. "Making Social Science Work Across Space and Time: A Critical Reflection on Robert Putnam's Making Democracy Work". American Political Science Review. 90(2): 389- 397 
Tillie, Jean. 2004. "Social Capital of Organisations and Their Members: Explaining the Political Integration of Immigrants in Amsterdam". Journal of Ethnic and Migration Studies 30(3): 529-541.

Tran Kelly, Stan Kustec and Tina Chui. 2005. "Becoming Canadian: Intent, Process and Outcome". Canadian Social Trends. Spring Statistics Canada Catalogue No. 11-008. Available: <http://www.statcan.gc.ca/studies-etudes/11-008/featurecaracteristique/5018920-eng.pdf $>$

Teorell, Jan. 2000. "A Resource Model of Political Participation: Networks Recruitment and Political Participation in Sweden". Paper presented to the ECPR Joint Session of Workshops, Copenhagen, 14- 19 April 2000.

Tocqueville, Alexis. 1969 [1935]. Democracy in America. Mayer, J.P. (ed.), George Lawrence (trans.). New York: Harper Row, Inc.

Togeby, Lise. 1999. "Migrants at the Polls: An Analysis of Immigrant and Refugee Participation in Danish Local Elections". Journal of Ethnic and Migration Studies 25(4): 665-684.

Uslaner, M. Eric. 2002. The Moral Foundations of Trust. Cambridge: Cambridge University Press.

Uhlaner, J. Carole. 1989. "Relational Goods and Participation: Incorporating Sociability into a Theory of Rational Action". Public Choice 62(3): 253-285

van Heelsum, Anja. 2002. "The Relationship Between Political Participation and Civic Community of Migrants in the Netherlands". Journal of Integration and Migration Studies 3(2): $179-200$.

Verba, Sidney and Norman H. Nie. 1972. Participation in America. Chicago: Chicago University Press.

Verba, Sidney, Kay L. Schlozman, Henry E. Brady and Norman, Nie .1993. "Race, Ethnicity and Political Resources". British Journal of Political Science 23(4): 453-97.

Verba, Sidney, Kay L. Schlozman and Henry E. Brady. 1995. Voice and Equality: Civic Volunteerism in American Politics. Cambridge MA: Harvard University Press.

White, Stephen, Neil Nevitte, André Blais, Elisabeth Gidengil and Patrick Fournier. 2008. "The Political Resocialization of Immigrants: Resistance or Life-Long Learning?" Political Research Quarterly 61(2): 268- 281.

White, Stephen, Neil Nevitte, Andre Blais, Joanna Everitt, Patrick Fournier and Elisabeth Gidengil. 2006. "Making Up for Lost Time: Immigrant Voter Turnout in Canada". Electoral Insight: Electoral Participation of Ethnocultural Communities 8(2) 11-16. 
Wood, R. John. 1981. “A Visible Minority Votes: East Indian Electoral Behaviour in the Vancouver South Provincial and Federal Elections of 1979". In Ethnicity, Power and Politics in Canada. Jorgen. Dahlie and Tissa Fernando (eds.). Toronto: Methuen. pp. 177-201.

Wolfinger, E. Raymond and Steven J. Rosenstone. 1980. Who Votes? New Haven: Yale University Press.

Wuthnow, Robert. 1999. "Mobilizing Civic Engagement: The Changing Impact of Religious Involvement". In Civic Engagement in American Democracy. Skocpol, Theda. and Morris P Fiorino (eds.). Washington DC: The Brookings Institution and Russell Sage Foundation. pp. 331- 363. 